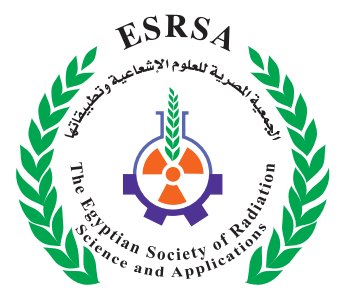

\title{
Sources of Radioelement's and REEs in The Stream Sediments Bounded by Abu Rusheid Gneiss South Eastern Desert, Egypt
}

Saleh, W.H.

Received: 05/01/2019

Accepted: 19/02/2019

E.mail:drwafaahosny@live.com

\section{KEYWORDS}

Abu Rushied,

Lamprophyers,

Granitic Gneiss,

REEs, Radioelement's.

\section{ABSTRACT}

Abu Rusheid area forms a NW-SE antiformal structure and it is truncated by a major fault in the north-west along wadi sikeit. Granitic gneisses rocks are cross cut by NNW-SSW trending altered and mineralized shear zone. The study area is bounded by longitude $34^{\circ} 48^{\prime} 34^{\circ} 48^{\prime}$ $30^{\prime \prime} \mathrm{E}$ and latitude $24^{\circ} 37^{\prime} 24^{\circ} 38^{\prime} \mathrm{N}$. This study aims to define sources and distribution of rare earth elements (REEs) and to describe the geochemical processes that govern mobility of $U$ and valuable radioelements, which comes from leaching of more labil REEs bearing minerals of granitic gneisses rocks, cut by mineralized shear zone and green silicates mainly amphiboles (hornblende). And mineralization extension according to grain sizes in trace elements.

The REEs in the stream sediments illustrate more than one depth, samples on the surface have +ve Eu anomaly, while the middle samples on depth $(0.5 \mathrm{~m}, 1 \mathrm{~m})$ are similar to each other but differ from surface samples and chondrite, where they depleted in -ve Eu and Tm. The bottom depth, at $(1.5 \mathrm{~m})$ europium, Tm began to increase. Negative europium anomaly maybe inherited from the felsic precursor rocks, a consequence of preferential leaching of Eu associated with the breakdown of feldspar (plagioclase) in direction of upstream sediments, suggesting that plagioclase free sediments are downstream in the studied area. At the surface contains high percentage of amphiboles, mainly (hornblende), iron oxide (geothite), few crystals of garnet, zircon and very fine monazite spots in

1. Nuclear Materials Authority, Cairo, Egypt 
allanite crystals embedded in silicate mineral. It is worthily that -ve Ce anomalies on surface and +ve Ce anomalies on $(0.5 \mathrm{~m}, 1 \mathrm{~m}, 1.5 \mathrm{~m})$ depth, otherwise some light REEs elements are depleted and sometimes increase, this may be explained by combined effect of selective remobilization of Ce (IV) could have been initiated during cycles of the stream sediments where chemically reworked.

Under surficial weathering (epigene), the breakdown of allanite give monazite, clay minerals, cerianite and geothite where $\mathrm{Ce}$ and $\mathrm{Nd}$ rich allanite indicate concentrated LREEs during a late hydrothermal alteration, geothite on surface represents the secondary phase and is considered as the main criteria for chemical weathering. Whilst HREEs increase at $(1 \mathrm{~m})$ depth where some minerals are concentrated (uranothorite, columbite), otherwise at depth $(0.5 \mathrm{~m})$ and $(1.5 \mathrm{~m})$ HREEs are similar due to the increase in zircon, xenotime, garnet and thorite. Enrichment in the middle REEs relative to the light and heavy REEs is chiefly controlled by hornblende, the REEs are compatible in hornblende in felsic and intermediate liquids and the highest partition coefficients are between Dy and Er. Mineralogical, this means the minerals seeming have undergone the dissolution of REEs in aqueous media at least once in history of REEs or might have been present in it, separated from the same original solution as liquid phase and solid phase.

The geochemical contour maps clarified the mineralization extension in deep levels from surface to $(0.5 \mathrm{~m}, 1 \mathrm{~m}, 1.5 \mathrm{~m})$ of stream sediments according to distribution in Wadi Abu Rusheid. We notice that valuable trace elements take the same direction of peralkalic granitic gneisses and lamprophyre dikes where $\mathrm{Zr}, \mathrm{Y}, \mathrm{Pb}$ and $\mathrm{Ga}$ in size $(-1+0.5)$ show the highest concentration in NNW-SSE direction and $\mathrm{Nb}$ in size $(-0.5+0.25)$ take the same direction, while higher concentration of $\mathrm{Zn}$ in size (-0.25) take NENW, otherwise U take NW-SE and Th take NW to NS direction. Uranium show relatively increase in
$(0.5 \mathrm{~m}, 1 \mathrm{~m})$ depth respectively, while Th increase at $(0.5 \mathrm{~m}, 1 \mathrm{~m}, 1.5 \mathrm{~m})$.

\section{INTRODUCTION}

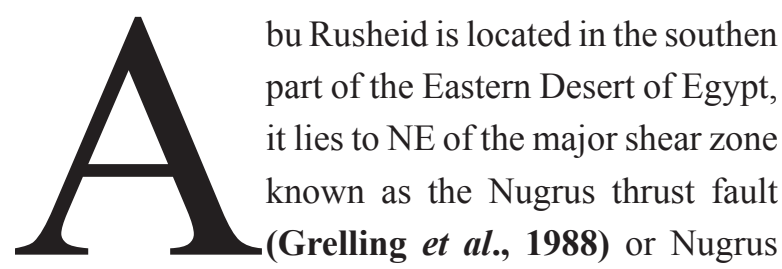
strike-slip fault (Fritz et al., 2002). Grelling et al. (1993) believe that shear zone in the pan African basement of the Eastern Desert may be related to compressional, as well as extensional stresses; however both types of deformation lead to antiformal structures on a regional scale. Abd EI Monem and Huraly (1979) estimated the age date of psammitic gneisses by zircon detrital age which ranges between $1120 \mathrm{Ma}$ and possibly $2060 \mathrm{Ma}$ suggesting that this basement may be, the so called Nile Craton, while Abu Rusheid granites is $610 \pm 20$ Ma determined by $\mathrm{Rb}$ - Sr method (Moghaz et al., 2004).

The present study shows some mineralization and paragensis. Also, geochemical studies of some valuable trace elements, in addition to measure $\mathrm{U}$ and Th with drawing contour maps indicating distribution, the direction of trace elements and $\mathrm{U}$, Th on it. Finally explain sources and controlling factors of the REEs distribution.

\section{Geologic setting}

Abu Rusheid area tectonostratigraphic succession forms a NW-SE antiformal structure, and it is truncated by a major fault in the north-west along wadi sikeit. The study area is bounded by longitude $34^{\circ} 48^{\prime} 34^{\circ} 48^{\prime} 30^{\prime \prime} \mathrm{E}$ and latitude $24^{\circ} 37^{\prime} 24^{\circ} 38^{\prime}$ $\mathrm{N}$ (Fig. 1), occupied by igneous and metamorphic rocks, the succession from old to young are arranged as follows: (1) ophiolitic melange, consisting of ultramafic rocks and layered metagabbros with a metasedimentary matrix; (2) cataclastic rocks (peralkalic granitic gneisses) in the core of the granitic pluton, 
which are composed of protomylonites, mylonites, ultramylonites and silicified ultramylonites, (3) mylonitic granites; and (4) post-granitic dikes and veins (Ibrahim et al., 2004). The cataclastic rocks (per alkalic granitic gneisses) are cross cut by NNWSSE trending altered and mineralized shear zone (Ali, 2012). The NNW-SSE lamprophyre dikes (L1 and L2, $0.5-1.0 \mathrm{~m}$ in width, $0.4-1.5 \mathrm{~km}$ in length) are located in the core of the cataclastic rocks (Ibrahim et al., 2015). Then, wadi deposits (stream sediments and stream course).

\section{Materials and Methodology of Study}

17 channel samples were collected from Wadi Abu Rusheid from pore holes having about $1 \mathrm{~m}$ diameter, and $1.5 \mathrm{~m}$ depth, on grid pattern of $25 \times 100$ $\mathrm{m}$ along profiles trending perpendicular to the wadi Fig.(2). The open pit divided vertically into $0.5,1$ and 1.5 meters. The average weight of each sample is about $10 \mathrm{~kg}$. The air-dried original sample was sieved using $2 \mathrm{~mm}$ screen. The obtained fraction less than $2 \mathrm{~mm}$ was quartered using June's splitters of different chutes, down to about $250 \mathrm{gm}$. Then the obtained representative sample is washed carefully several times to clarify it from silt and clay. Hydrogen peroxide was used to get rid of the organic matters.

A representative sub-sample weighting about 60 gm was taken from each prepared sample by quartering for mineral separation. Separation was conducted using bromoform (Sp. Gr. $2.86 \mathrm{~g} / \mathrm{cm}^{3}$ ) and magnetic fractionation using a Frantz Isodynamic Magnetic Separator (Model L-1). Mineralogical identification of the mineral constituents recognized by stereomicroscope and their composition confirmed by environmental Semi-quantitative EDX chemical analysis, using Phillips XL-30 Environmental Scanning Electron Microscope (ESEM).

The 17 sample are split to 45 fraction samples $(-0.25,-0.5+0.25,-1+0.5)$. The obtained fractions were analyzed for some trace elements. The elements were determined by X-ray fluorescence spec- trometer model (X-Uniqu II) by perssion $10 \%$. The uranium and thorium were detected chemically by Control analysis method of uranium in the different aqueous stream solutions as well as in the product has been undertaken by the oxidimetric titration after its reduction using a standard solution of ammonium metavanadat (Mathew et al., 2009). This has been possible after a prior uranium reduction step using ammonium ferrous sulfate. In this procedure, di-phenyl sulphonate has been used as indicator where upon its color would change to a slightly violet red color. Thorium is chemically determined by the colored method using Arsenazo-III, as an indicator. The colored method was performed using a spectrophotometer technique (Merczenko, 1986). REEs measured by inductively coupled plasmamass spectrometry (ICP-MS) at the analytical laboratory (N.M.A).

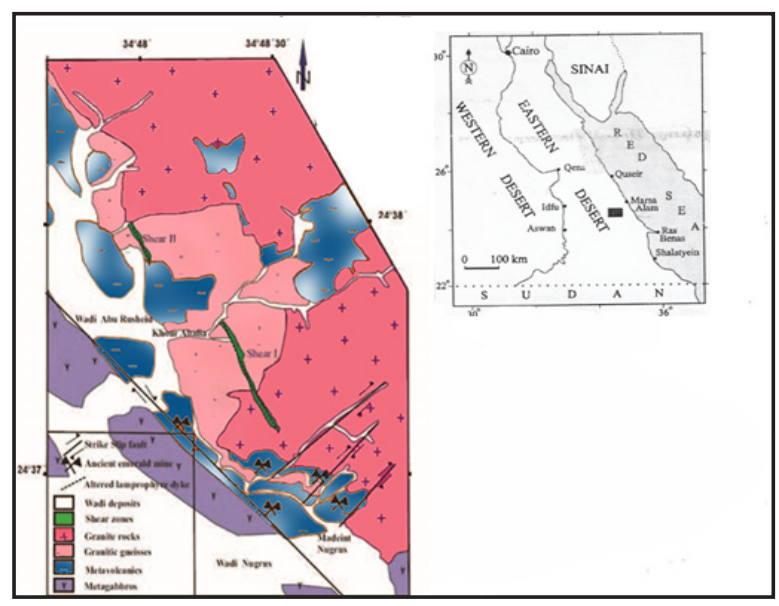

Fig. (1): Geological map of Abu Rusheid area (modified by Ali, 2012 after Ibrahim et al., 2004).

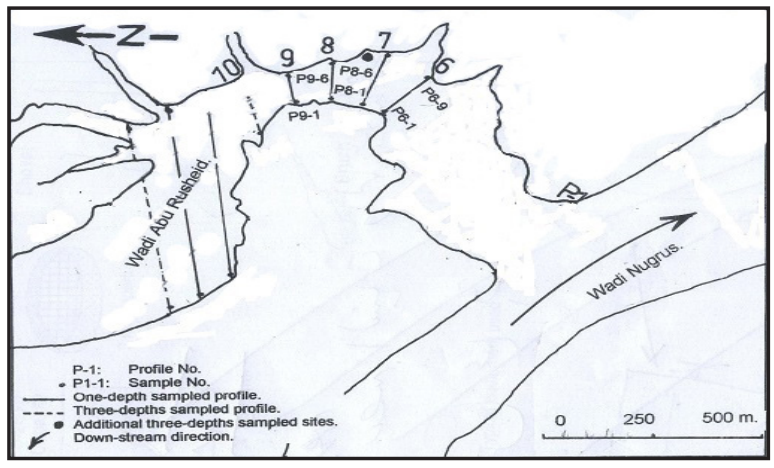

Fig. (2): Sample location map (Internal report N.M.A., 2003). 


\section{Mineralization and paragenesis}

Abu Rusheid area is subjected to hypothesis, was given by (Bugrov et al., 1973). They concluded that radioactive rock is not a part of psammitic gneiss, but it is an apogranite (albitized granite) still concordant along the contact between the overlying schist and the under lying psammitic gneiss. This still represents an offshoot of a hidden apogranite intrusion.

Hilmy et al. (1990) suggested model for the redistribution of minerals, proposed that mineralization might have taken place is believed to have involved the interaction between the gneiss formation enriched in elements, on one hand and the fluorine and hot gases phase. On the other hand, the breakdown of primary minerals such as zircon, columbite - tantallite etc. is attributed to a period of short duration of high interaction with the rock, rare elements $\mathrm{Zr}, \mathrm{Nb}$, Sn etc. The existence of $\mathrm{U}$, Th and $\mathrm{K}$ in the original rock before alteration or mineralization can produce a hot rock district which will promote the convection process. The convection from a deep seated source was under considerable pressure. The gases infiltrated through fissures and cracks reaching the upper zone. Then the attraction process took place causing the redistribution of the mineralogical investigation of REE- minerals and radioactive - bearing minerals in the studied area.

Abdalla et al. (1996), ElAfandy et al. (2000) the granitic gneiss commonly display vertical petrographical zoning with a lower unaltered zone of alkali feldspar granites, a middle microclinized granite (zone of K-metasomatism). In addition, upper bleached grey to whitish albitized granite (zone of $\mathrm{Na}$ metasomatism). A small volume of graisenizy $\left(\mathrm{H}^{+}\right.$ - metasomatized) of silicified granites.

Ali et al. (2011) studied the mineralogy and shear zone and proved on the basis of field evidence, textural relations and composition of ore minerals, that the main mineralization event was magmatic $(629 \pm 5$ Ma, CHIME monazite), with later hydrothermal alteration and local remobilization of high field strength elements.

Ibrahim et al. (2015) studied the lamprophyre dikes and stated the NNW-SSE lamprophyre dikes $\left(\mathrm{L}_{1}\right.$ and $\left.\mathrm{L}_{2}\right)$ are located in the core of the cataclastic rocks and the feldspars, micas in both $\mathrm{L}_{1}$ and $\mathrm{L}_{2}$ are partially altered to clay minerals (chemical traps) while the oxidation of sulfide minerals left ocelli (physical traps) usually filled by calcite and uranium minerals.

For the above reasons we studied the relation between some minerals on the surface and relatively some depths of stream sediments bounded by gneiss at $0.5,1$ and 1.5 meters. The collected samples composed of green silicate represented mainly by amphiboles with few crystals of plagioclase and pyroxene, flakes of biotite and muscovite. Heavy minerals are rare in the surface samples and recorded in the deeper samples. The deepest samples encloses high percentage of the heavy minerals.

\section{Samples at the surface}

Includes high percentage of amphiboles, (mainly hornblende) iron oxide (geothite), few crystals of garnet, zircon and very fine monazite spot in allanite crystals embedded in silicate mineral.

Amphibole, $\mathrm{Ca}_{2}(\mathrm{MgFe})_{5} \mathrm{Si}_{8} \mathrm{O}_{22}(\mathrm{OH})$ :

Amphipole is one of the green silicate present as euhedral crystals of monoclinic system and prismatic form. Its characterized by dark green color with mild transparency and vitreous luster, Fig (3B).

\section{Geothite, $\mathrm{FeO}(\mathrm{OH})$ :}

Iron bearing hydroxide mineral, It forms through the weathering of other iron-rich minerals, and thus is a common component of soils, concentrated stream sediments present as concretions with brownish black color, it's brittle characterized by submetallic luster and complete opacity and low magnetism Fig (3A). 
Allanite, $(\mathrm{Ce}, \mathrm{Ca}, \mathrm{Y})_{2}(\mathrm{Al}, \mathrm{Fe})_{3}(\mathrm{SiO})_{3} \mathrm{OH}$ :

Allanite was recorded as an accessory mineral in granites, generally the Ce-rich allanite indicates the much-localized remobilization and concentration of REEs during a late hydrothermal alteration (Yuanming and Micheals, 1991). The highest LREE contents relative to the HREE indicating magmatic allanite (Spurgin et al., 2009). The studied allanite has been supported by the presence of Nd-rich allanite, the highest $\mathrm{Nd}$ content Fig. (3c) relatively at high $\mathrm{PH}$ condition, calcium $\mathrm{Ca}$ and $\mathrm{Si}$ are the most easily solublized and $\mathrm{Al}$ in mobile, while Fe is very resistant to desolution and completely preciptated as ferruginous mainly geothite (Taylor and Eggleton,
2001), the recorded geothite represents the secondary phase and is considered as the main criteria for chemical weathering and reflecting the influence of different weathering stages. This result concides with that of (Price et al., 2005).

The breakdown of allanite under surficial weathering (epigene) condition can be described as follows: Allanite + Fluids $\quad$ Cerianete + Monazite + clay minerals + geothite (Meintzer and Mitchelle, 1982).

Wood and Rickette (2000) reported that allanite was most commonly replaced by a LREE-Th phosphate phase possibly disrupted monazite $\mathrm{Nd}((\mathrm{Nd}$, $\mathrm{Ce}, \mathrm{La}, \mathrm{Sm}, \mathrm{Th}) \mathrm{PO}_{4}$ ). due to intense weathering.
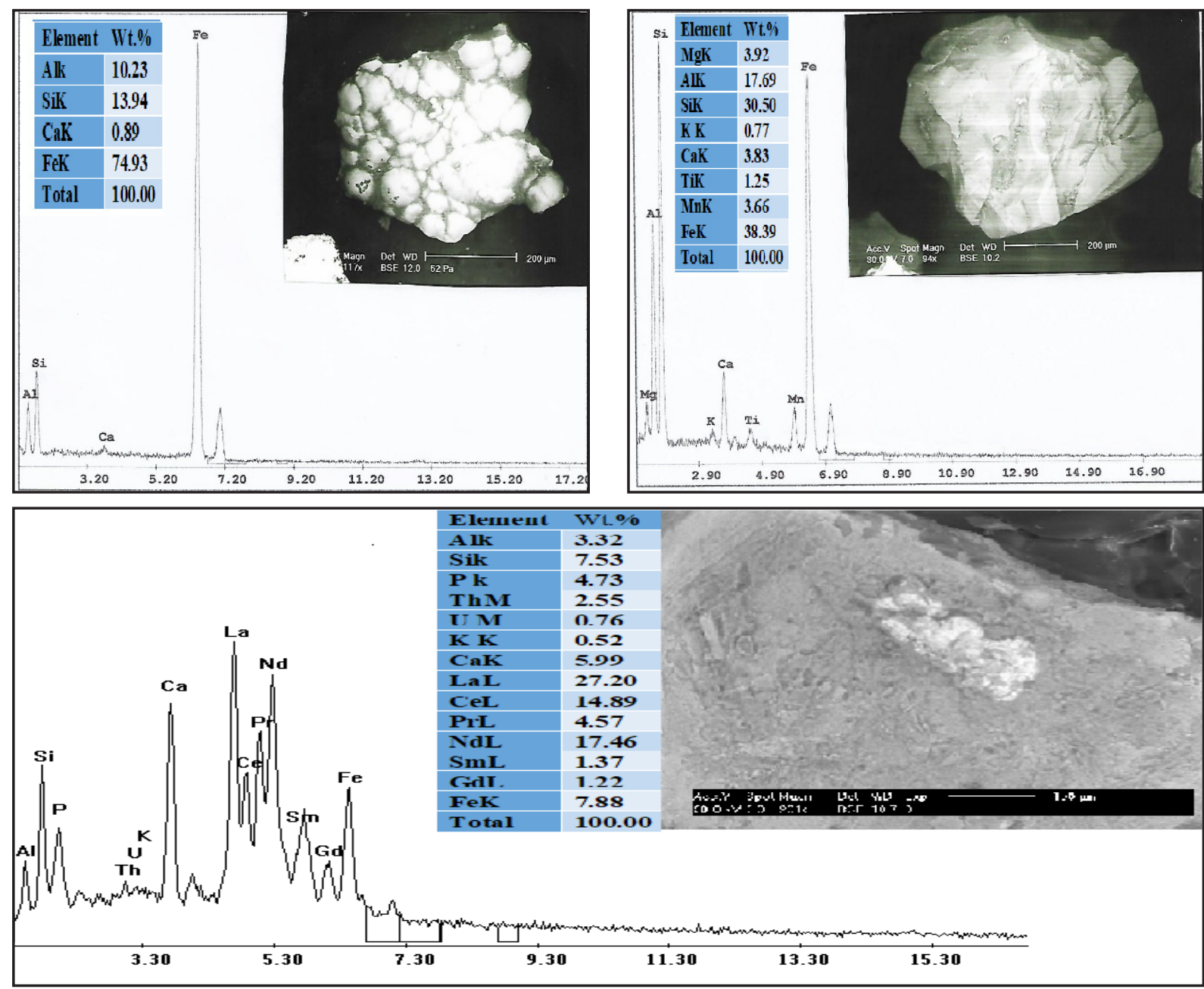

Fig. (3): ESEM image and EDX spectra of a) Geothite, b) Amphibole, c) Allanite at the surface. 


\section{Half meter (0.5m) samples:}

Garnet, ( $\mathrm{Ca}, \mathrm{Mg}, \mathrm{Fe}, \mathrm{Mn})_{3} \mathrm{Al}_{2} \mathrm{Si}_{3} \mathrm{O}_{12}$ :

In the studied area we find high percentage of garnet Fig. (4a, b), of first and second type pryropealmandine and almandine-spresstine inaddition to zircon of short and long type.The minerals formed during the thermal metamorphism such as garnet, reflecting the mild stress regime during thermal metamorphism. Therefore, the absence of shearing stress in thermal metamorphism allows destroying the almandine garnet and the appearance of spressartitealmandine instead, sometimes before the formation of biotite. Garnet group consist of iron almunium silicate with chemical formula $(\mathrm{Ca}, \mathrm{Mg}, \mathrm{Fe}, \mathrm{Mn})_{3} \mathrm{Al}-$ $\left.{ }_{2} \mathrm{Si}_{3} \mathrm{O}_{12}\right)$, the garnet group can be divided in two sub groups based on different ionic radii of $\mathrm{Mg}, \mathrm{Fe}, \mathrm{Mn}$ on one hand and $\mathrm{Ca}$ on the other, the first type pyrolspite consists of pyrope (Mg, Al)- almandine (Fe, Al) and spessartine (Mn, Al), the second type grondites include $\mathrm{Ca}$ in the structure.

Xenotime, $\mathrm{Y}\left(\mathrm{Po}_{4}\right)$ :

Also, we find xenotime is enriched in HREE (especially $\mathrm{Yb}, \mathrm{Er}, \mathrm{Dy}$ ), $\mathrm{Y}$ as in Fig. (4c, d). xenotime can be used as a sensitive trace element geothermometer, both with monazite - xenotime pair (Andrehs and HeinRich, 1998). So, after Ali (2012), xenotime from Abu Rusheid lamprophyre dyke formed at a temperature around 600 .

Zircon, $\left(\mathrm{ZrSiO}_{4}\right)$ :

Occurs as euhedral six-sided or eight-sided prismatic crystals. It's mainly colourless to pale yellow. Also, possessing various colours reddish borwnreddish orange. Vavra (1990) proposed that zircon shape is a function of conditions of environment of crystallization. In particular, formation of bipyramidal faces is related to slow crystallization as Fig. (4e). Also, some of the studied grains show lengthening where a high fluid content causes the prided of zircon crystallization to lengthen (Pupin et al.,
1978) some crystals show preferential growth of the pyramidal faces at the expense of prismatic one.

\section{One meter (1m) samples:}

Some samples record existence of uranothorite, columbite with $\mathrm{Nb}$ - Ta ratio (54.48 - 3.89), Also we notice presence of cassterite $\left(\mathrm{SnO}_{2}\right)$ and tourmaline.

Tourmaline, (Ca, K, $\mathrm{Na})(\mathrm{Al}, \mathrm{Fe}, \mathrm{Li}, \mathrm{Mg}$, $\mathrm{Mn})_{3}(\mathrm{Al}, \mathrm{C}, \mathrm{Fe}, \mathrm{V})_{6}\left(\mathrm{BO}_{3}\right)_{3}(\mathrm{Si}, \mathrm{Al}, \mathrm{B})_{6} \mathrm{O}_{18}(\mathrm{OH}, \mathrm{F})_{4}$ :

Crystalline boron silicate mineral compounded with elements such as aluminium, iron, magnesium, $\mathrm{Na}$ and $\mathrm{Li}$ of potassium, of trigonal crystal system with variety of colors most commonly black but can range from colourless to brown red Fig. (4f).

Crystallization immediately after the main phase of crystallization of acidic melts adjacent to the contact rocks, (tourmalization at the expense of biotite) as pneumatically formed mineral in contact metamorphism, tourmaline occur in most granitic, pegmatites and quartz, tourmaline veins and is a common mineral in most medium to high grade metamorphic rocks with topaz-beryl-cassterite fluorite.

\section{Uranothorite, $\mathrm{Th}, \mathrm{U}\left(\mathrm{SiO}_{4}\right)$ :}

The studied uranothorite generally occurs as the anhedral opaque mineral grains vary in color from dark brown to black and exhibiting submetallic to greasy luster Fig.(5a), the ESEM analysis shows it consists essentially of $\mathrm{ThO}_{2}$ and $\mathrm{SiO}_{2}$ which exceeds significantly $\mathrm{UO}_{2}$. According to Heinrich (1958) uranium is usually present in amounts up to $10 \%$ in this mineral. Trace elements of $\mathrm{Ca}, \mathrm{Al}$ and $\mathrm{P}, \mathrm{Fe}$ and Y occur in more abundant amounts Fig. (5a).

Columbite, (Fe, $\mathrm{Mn}, \mathrm{Mg})(\mathrm{Nb}, \mathrm{Ta})_{2} \mathrm{O}_{6:}$

Several columbite crystals have been subjected to semiquantitaive analyses and the obtained SEM data show that both $\mathrm{Nb}$ and $\mathrm{Fe}$ are the essential component together with minor of Ta, Th, U, Na, K and $\mathrm{Mg}$. The grains are black in colour and possess abrilliant metallic luster under binocular microscope. The 
grains are present in the form of massive rounded to subrounded containing surface cavities, Fig. (5b). The second variety occurs in form of irregular grains
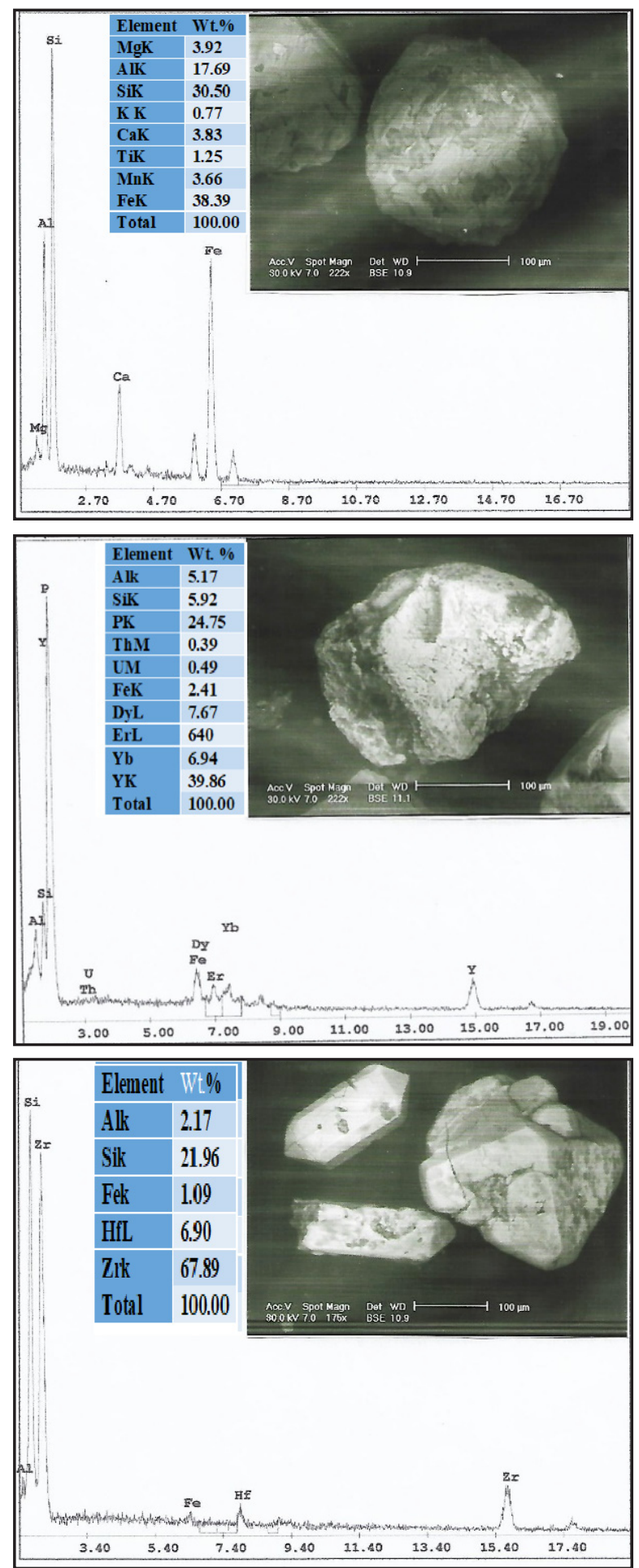

Fig. (5c). Indeed $\mathrm{Nb}$ and Ta mineralization are generally associated with Hf-rich zircon.
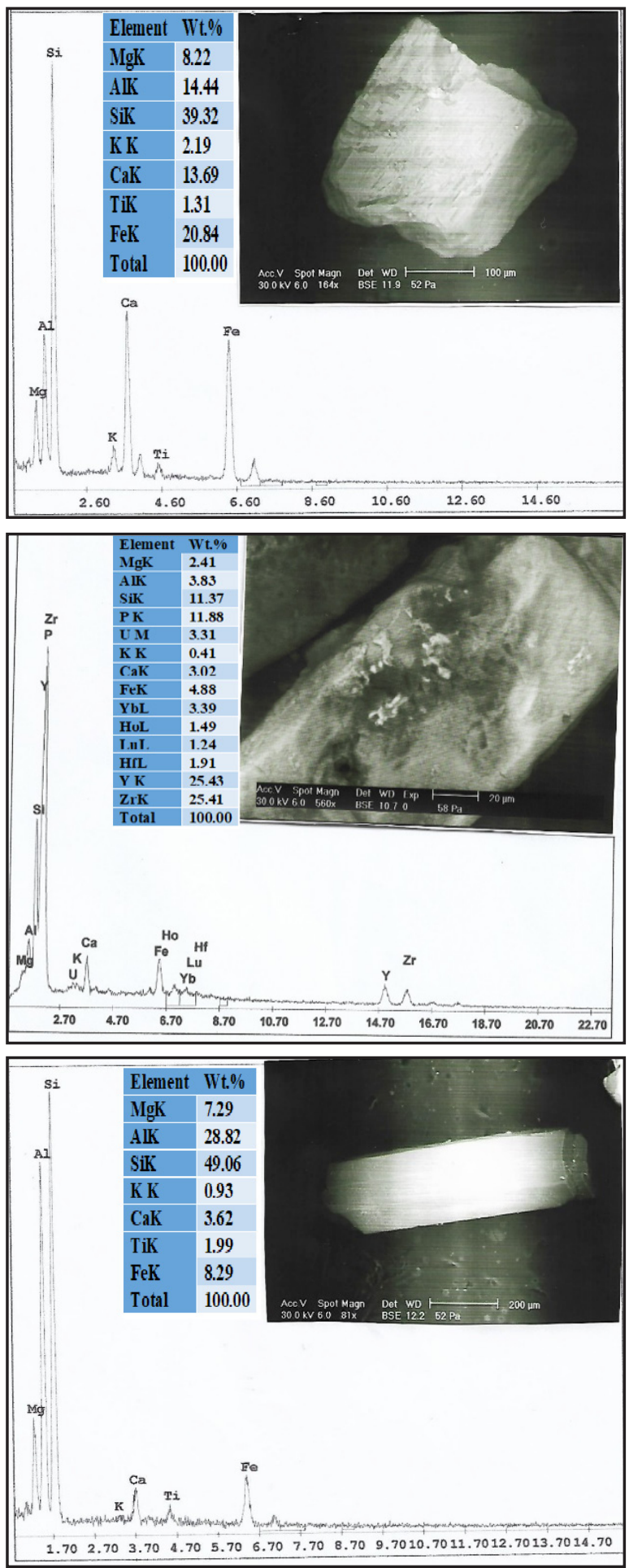

Fig. (4): ESEM image and EDX spectra of a) Garnet Pyrope - Almandine, b) Garnet Almandine spresstine, c) Xenotime, d) Xenotime in Zircon at depth $0.5 \mathrm{~m}$, e) Short + long Zircon at depth $0.5 \mathrm{~m}, \mathrm{f}$ )Tourmaline at depth $1 \mathrm{~m}$. 


\section{Cassterite, $\left(\mathrm{SnO}_{2}\right)$ :}

It is a tin oxide mineral, generally opaque but it's translucent in thin crystals, its luster and multi-
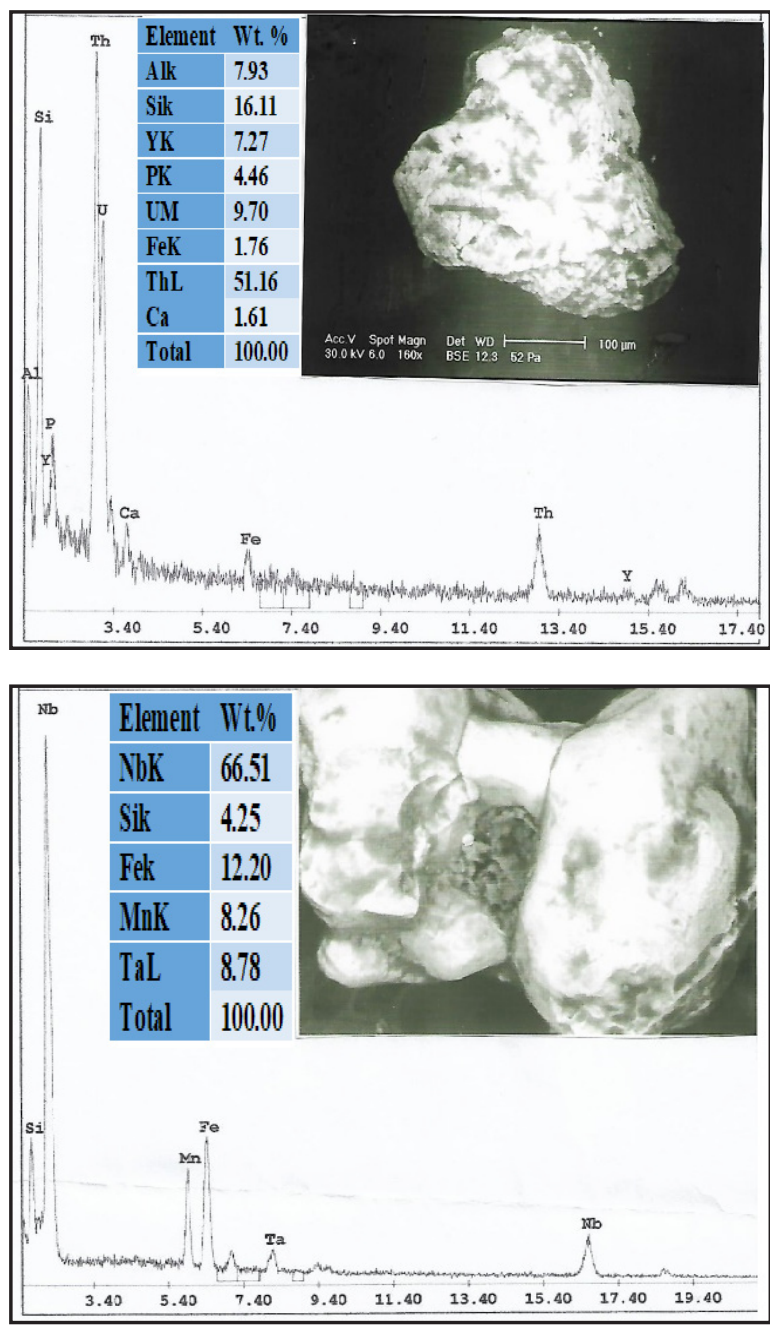

ple faces produce a desirable gem, has formula $\mathrm{SnO}_{2}$ and crystal system tetragonal. Tin shows a chemical similarity to both of it's neighbours in group 14, germanium and lead Fig.(5d).
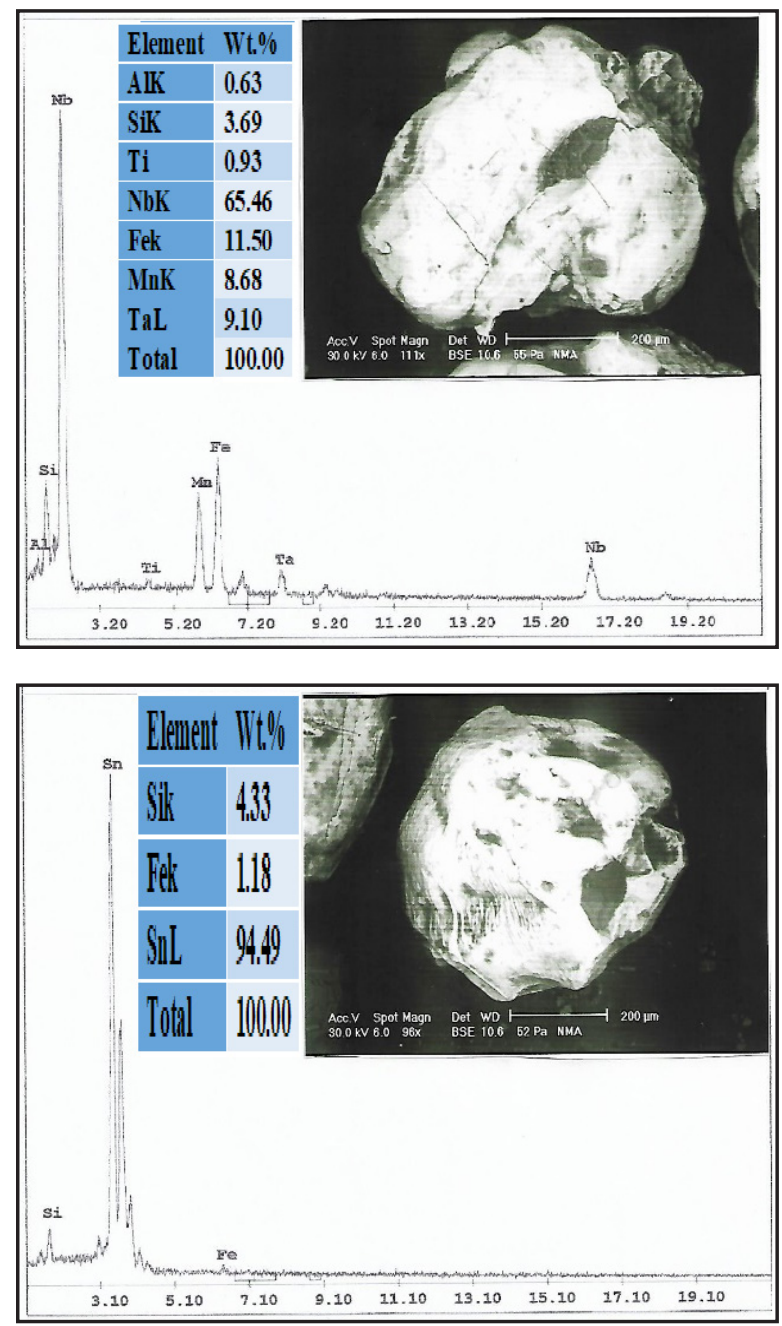

Fig. (5): ESEM image and EDX spectra of a) Uranothorite, b) Columbite, c) of Columbite, d) Cassterite at depth $1 \mathrm{~m}$.

One and $a$ half meter $(1.5 \mathrm{~m})$ samples:

At the end of one meter and half $(1.5 \mathrm{~m})$ we can identify zircon bipyramid with ratio of HF (1.97) and Thorite $\left(\mathrm{Th}_{\mathrm{SiO}}\right)$ in addition to garnet and columbite. So that, $\mathrm{Zr}$ and $\mathrm{Th}$ are generally considered as highly immobile elements.

\section{Zircon, $\left(\mathrm{ZrSiO}_{4}\right)$ :}

While the formation of the prismatic faces is a function of temperature and degree of zirconium supersaturation in the liquid. However, Speer (1982) concluded that it is difficult to relate the morphology to any condition Fig. (6a).

\section{Thorite, $\mathrm{ThO}_{2}\left(\mathrm{SiO}_{2}\right)$ :}

A common radioactive mineral brown to black in colour, The ESEM analysis shows that thorite consists essentially $\mathrm{ThO}_{2}$ and $\mathrm{SiO}_{2}$.Other elements detected in small to minor amount are $\mathrm{Ca}, \mathrm{Mg}, \mathrm{P}, \mathrm{Si}$ 
and fe, whereas rare earth were not detected in the analysed thorite Fig.(6b). According to Frondel and Cuttito (1955), thorite form hydrothermally over

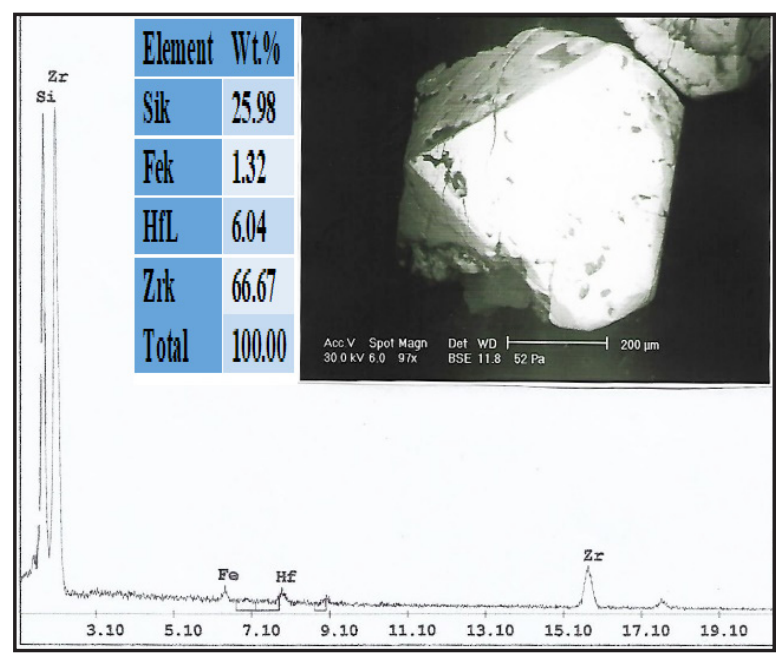

temperature range ( $300 \mathrm{C}$ to $700 \mathrm{C}$ ), the formation of thorite is favoured by acid condtion.

Fig. (6): Show ESEM image and EDX spectra of a) short Zircon, b) Thorite at depth $1.5 \mathrm{~m}$.
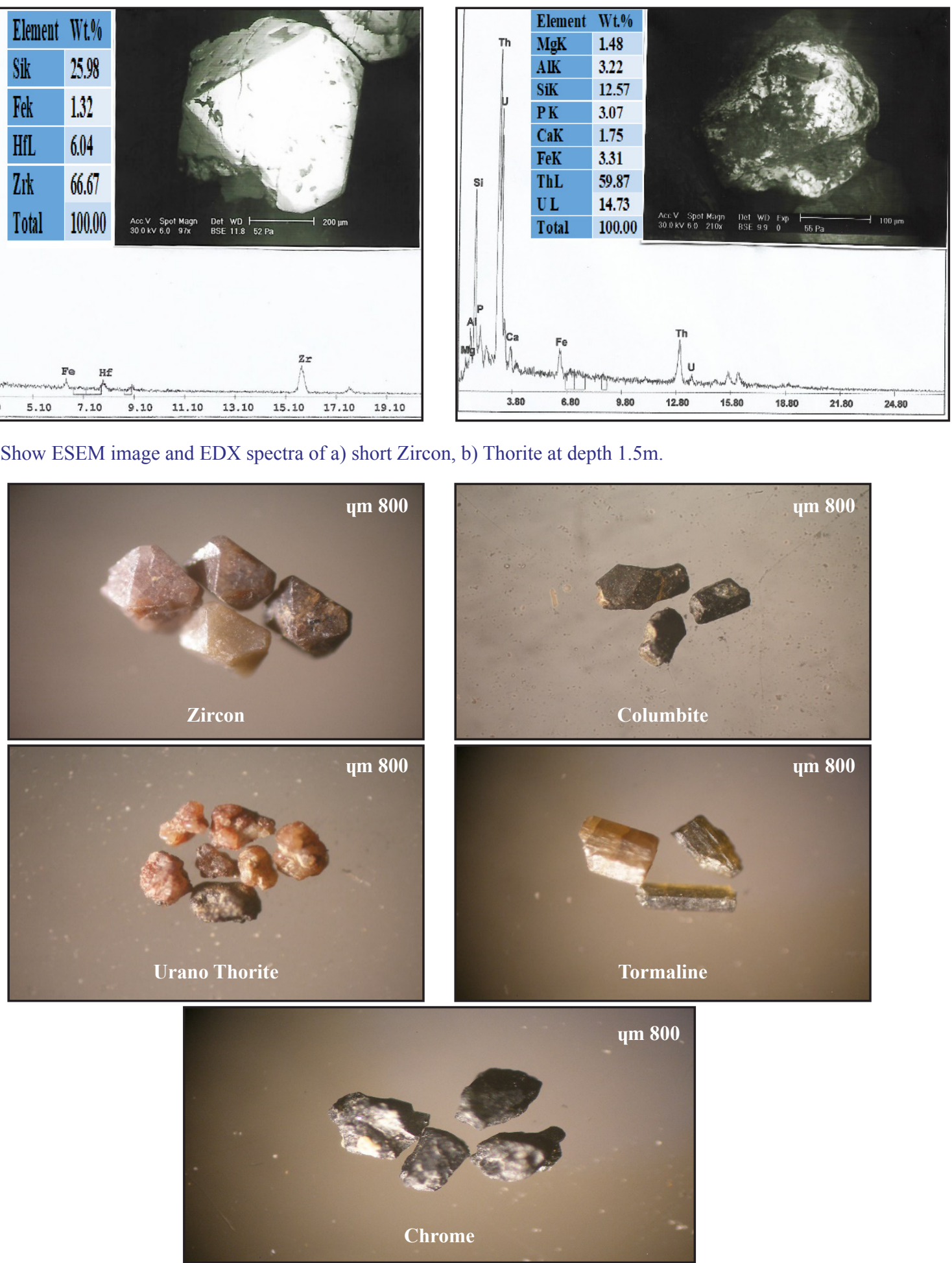

Fig. (7): Show some minerals under binuclear microscope. 


\section{Geochemical studies:}

The elements AL, Ti, Zr, HF, Th, Ga, Cr and REE are considered immobile elements during alteration processes (Maclean and Kranidiotis, 1987; Liaghat et al., 2003\& Calagari and Abedini, 2007). So, in the study area trace elements are richer in $\mathrm{Zr}$, $\mathrm{Nb}, \mathrm{Y}, \mathrm{Sr}, \mathrm{Ba}, \mathrm{V}$ and $\mathrm{Cr}$, some diagrams are drawn to indicate the relation between some elements as shown in table (1).

$\mathrm{Zr}$ and $\mathrm{Y}$ increases with $\mathrm{Nb}$ increasing Fig. 8(b, e). While, Y slightly increase with Zr increase Fig. (8d) and $Y$ with vanadium show increase relation Fig. (8c) also. While, Ga increase and vanadium decrease Fig. (8a).

Table (1): Trace elements concentration in ppm of the studied Abu Rusheid stream sediment.

\begin{tabular}{|c|c|c|c|c|c|c|c|c|c|c|c|c|c|}
\hline $\begin{array}{c}\text { Sample } \\
\text { size }\end{array}$ & $\mathrm{Cr}$ & $\mathbf{N i}$ & $\mathrm{Cu}$ & $\mathbf{Z n}$ & $\mathbf{Z r}$ & $\mathbf{R b}$ & $\mathbf{Y}$ & Ba & $\mathbf{P b}$ & $\mathrm{Sr}$ & $\mathbf{G a}$ & $\mathbf{V}$ & $\mathbf{N b}$ \\
\hline $\begin{array}{c}6-1 \\
-0.25\end{array}$ & 30 & 25 & 9 & 47 & 134 & u.d & 37 & 91 & 19 & 6 & 15 & 10 & 22 \\
\hline $\begin{array}{c}6-1 \\
-0.5+0.25 \\
\end{array}$ & 447 & 116 & 13 & 146 & 2642 & 33 & 1592 & 6781 & 24 & 141 & 22 & 170 & 497 \\
\hline $\begin{array}{c}6-1 \\
-1+0.5\end{array}$ & 373 & 140 & 14 & 168 & 1639 & 47 & 775 & 4916 & 23 & 86 & 15 & 130 & 306 \\
\hline $\begin{array}{c}6-2 \\
-0.25\end{array}$ & 541 & 80 & 10 & 116 & 5011 & 5 & 2310 & $>10000$ & 26 & 266 & 20 & 217 & 947 \\
\hline $\begin{array}{c}6-2 \\
-0.5+0.25\end{array}$ & 359 & 117 & 12 & 149 & 1831 & 36 & 871 & 5731 & 23 & 98 & 14 & 154 & 342 \\
\hline $\begin{array}{c}6-2 \\
-1+0.5\end{array}$ & 481 & 98 & 13 & 148 & 3122 & 11 & 1444 & 9747 & 28 & 165 & 19 & 214 & 587 \\
\hline $\begin{array}{c}6-6 \\
-0.25\end{array}$ & 578 & 78 & 9 & 138 & 6407 & 2 & 3019 & 9895 & 42 & 336 & 35 & 238 & 1208 \\
\hline $\begin{array}{c}6-6 \\
-1+0.5\end{array}$ & 456 & 134 & 15 & 218 & 4026 & 48 & 1909 & 6147 & 58 & 212 & 43 & 155 & 756 \\
\hline $\begin{array}{c}6-8 \\
-1+0.5\end{array}$ & 674 & 157 & 6 & 279 & 8720 & 95 & 4083 & 4808 & 138 & 461 & 110 & 124 & 1639 \\
\hline $\begin{array}{c}8-1 \\
-0.5+0.25\end{array}$ & 380 & 101 & 12 & 133 & 1200 & 20 & 269 & 7694 & 21 & 63 & 13 & 204 & 223 \\
\hline $\begin{array}{c}8-3 \\
-0.5+0.25\end{array}$ & 423 & 97 & 10 & 132 & 2277 & 24 & 1085 & 6999 & 31 & 122 & 25 & 188 & 427 \\
\hline $\begin{array}{c}8-4 \\
-0.5+0.25 \\
\end{array}$ & 560 & 88 & 12 & 143 & 3714 & 9 & 1764 & $>10000$ & 31 & 198 & 26 & 262 & 698 \\
\hline $\begin{array}{c}8-5 \\
-0.5+0.25\end{array}$ & 480 & 76 & 9 & 131 & 3451 & 11 & 1637 & 9156 & 34 & 181 & 30 & 236 & 647 \\
\hline $\begin{array}{c}8-6 / 1 \\
-0.5+0.25 \\
\end{array}$ & 739 & 163 & u.d & 445 & $>10000$ & 32 & $>10000$ & 2026 & 287 & 1416 & 254 & 66 & 5227 \\
\hline $\begin{array}{c}8-6 / 10 \\
-0.5+0.25 \\
\end{array}$ & 1043 & 140 & u.d & 305 & $>10000$ & u.d & $>10000$ & 5210 & 343 & 2123 & 291 & 145 & 7909 \\
\hline $\begin{array}{c}8-6 / 100 \\
-0.5+0.25\end{array}$ & 822 & 112 & u.d & 366 & $>10000$ & u.d & $>10000$ & 5973 & 339 & 2223 & 303 & 145 & 8320 \\
\hline $\begin{array}{c}9 / 1 \\
-0.5+0.25\end{array}$ & 1093 & 195 & 3 & 642 & $>10000$ & 137 & $>10000$ & 1327 & 380 & 1513 & 313 & 50 & 5556 \\
\hline $\begin{array}{c}9 / 4 \\
-0.5+0.25\end{array}$ & 491 & 147 & 16 & 254 & 5157 & 63 & 2442 & 5439 & 81 & 274 & 63 & 136 & 966 \\
\hline
\end{tabular}




\begin{tabular}{|c|c|c|c|c|c|c|c|c|c|c|c|c|c|}
\hline $\begin{array}{c}9 / 10 \\
-0.5+0.25\end{array}$ & 906 & 165 & u.d & 1356 & $>10000$ & 89 & 8420 & 1107 & 340 & 942 & 274 & 47 & 3419 \\
\hline $\begin{array}{c}9 / 100 \\
-0.5+0.25 \\
\end{array}$ & 903 & 153 & u.d & 328 & $>10000$ & 23 & $>10000$ & 945 & 367 & 1311 & 301 & 42 & 4848 \\
\hline $\begin{array}{c}8-1 \\
-0.25 \\
\end{array}$ & 339 & 113 & 16 & 126 & 1917 & 22 & 908 & 5792 & 17 & 98 & 24 & 133 & 350 \\
\hline $\begin{array}{c}8-1 \\
-1+0.5\end{array}$ & 374 & 114 & 16 & 134 & 1729 & 19 & 818 & 7694 & 25 & 86 & 22 & 171 & 314 \\
\hline $\begin{array}{c}8-2 \\
-0.25 \\
\end{array}$ & 679 & 76 & 14 & 110 & 6394 & 11 & 3017 & 1045 & 33 & 330 & 26 & 240 & 1179 \\
\hline $\begin{array}{c}8-2 \\
-1+0.5 \\
\end{array}$ & 388 & 117 & 12 & 127 & 3009 & 37 & 1426 & 5526 & 25 & 156 & 21 & 125 & 553 \\
\hline $\begin{array}{c}8-3 \\
-0.25 \\
\end{array}$ & 582 & 92 & 13 & 138 & 7007 & 9 & 3304 & $>10000$ & 29 & 356 & 33 & 221 & 1287 \\
\hline $\begin{array}{c}8-3 \\
-1+0.5 \\
\end{array}$ & 322 & 117 & 9 & 124 & 1973 & 41 & 936 & 5625 & 27 & 100 & 21 & 140 & 360 \\
\hline $\begin{array}{c}8-4 \\
-0.25\end{array}$ & 428 & 75 & 6 & 100 & 5280 & 8 & 2493 & 9718 & 28 & 275 & 19 & 223 & 969 \\
\hline $\begin{array}{c}8-4 \\
-1+0.5 \\
\end{array}$ & 417 & 103 & 11 & 130 & 2786 & 30 & 1322 & 7153 & 28 & 142 & 26 & 179 & 509 \\
\hline $\begin{array}{c}8-5 \\
-0.25 \\
\end{array}$ & 507 & 77 & 5 & 103 & 5337 & 9 & 2521 & $>10000$ & 33 & 271 & 23 & 245 & 981 \\
\hline $\begin{array}{c}8-5 \\
-1+0.5 \\
\end{array}$ & 356 & 104 & 11 & 143 & 2219 & 42 & 1055 & 6093 & 30 & 111 & 21 & 159 & 404 \\
\hline $\begin{array}{l}8-6 / 1 \\
0.25 \\
\end{array}$ & 781 & 133 & U.D & 217 & $>10000$ & U.D & 9979 & 5557 & 187 & 1061 & 183 & 125 & 3952 \\
\hline $\begin{array}{c}8-6 / 1 \\
-1+0.5 \\
\end{array}$ & 755 & 167 & U.D & 345 & $>10000$ & 73 & $>10000$ & 2349 & 384 & 2543 & 382 & 61 & $>10000$ \\
\hline $\begin{array}{c}8-6 / 10 \\
0.25\end{array}$ & 627 & 119 & U.D & 229 & $>10000$ & U.D & $>10000$ & 5471 & 194 & 1090 & 183 & 122 & 4063 \\
\hline $\begin{array}{l}8-6 / 10 \\
-1+0.5 \\
\end{array}$ & 809 & 142 & U.D & 300 & $>10000$ & 97 & $>10000$ & 3907 & 305 & 1965 & 300 & 93 & 7306 \\
\hline $\begin{array}{c}8-6 / 100 \\
0.25 \\
\end{array}$ & 612 & 129 & U.D & 220 & $>10000$ & 20 & 8374 & 5044 & 176 & 882 & 155 & 123 & 3315 \\
\hline $\begin{array}{c}8-6 / 100 \\
-1+0.5 \\
\end{array}$ & 625 & 123 & U.D & 331 & $>10000$ & 45 & $>10000$ & 4170 & 345 & 2348 & 340 & 96 & 9068 \\
\hline $\begin{array}{c}9 / 1 \\
-0.25 \\
\end{array}$ & 853 & 137 & U.D & 231 & $>10000$ & U.D & $>10000$ & 4484 & 189 & 1062 & 181 & 106 & 3985 \\
\hline $\begin{array}{c}9 / 1 \\
-1+0.5\end{array}$ & 990 & 303 & U.D & 761 & $>10000$ & 217 & $>10000$ & 1118 & 313 & 1366 & 297 & 42 & 5032 \\
\hline $\begin{array}{c}9 / 4 \\
-0.25 \\
\end{array}$ & 395 & 91 & 4 & 128 & 7433 & 12 & 3498 & 8268 & 50 & 376 & 46 & 194 & 1367 \\
\hline $\begin{array}{l}9 / 100 \\
-0.25 \\
\end{array}$ & 781 & 158 & U.D & 238 & $>10000$ & U.D & $>10000$ & 3705 & 306 & 1118 & 275 & 95 & 4281 \\
\hline $\begin{array}{r}9 / 100 \\
-1+0.5 \\
\end{array}$ & 989 & 189 & 8 & 503 & $>10000$ & 108 & $>10000$ & 1023 & 442 & 1407 & 424 & 45 & 5220 \\
\hline
\end{tabular}


All sample number in size $0.25,-0.5+0.25,-1.0$ depth $1 \mathrm{~m}, 8-6 / 100$ and $' 9 / 100 \rightarrow$ represents sizes on +0.5 , while $8-6 / 1,9 / 1$ and ' $9 / 4 \rightarrow$ represents sizes on depth $1.5 \mathrm{~m}$ depth $0.5 \mathrm{~m}, 8-6 / 10$ and $' 9 / 10 \rightarrow$ represents sizes on

a)

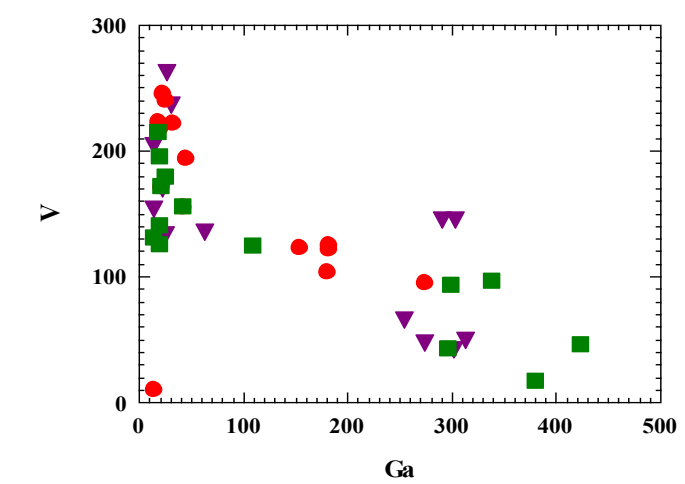

c)

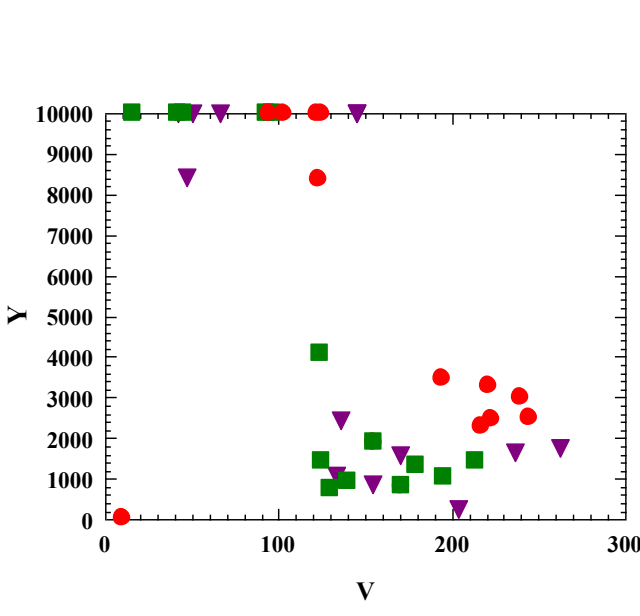

e)

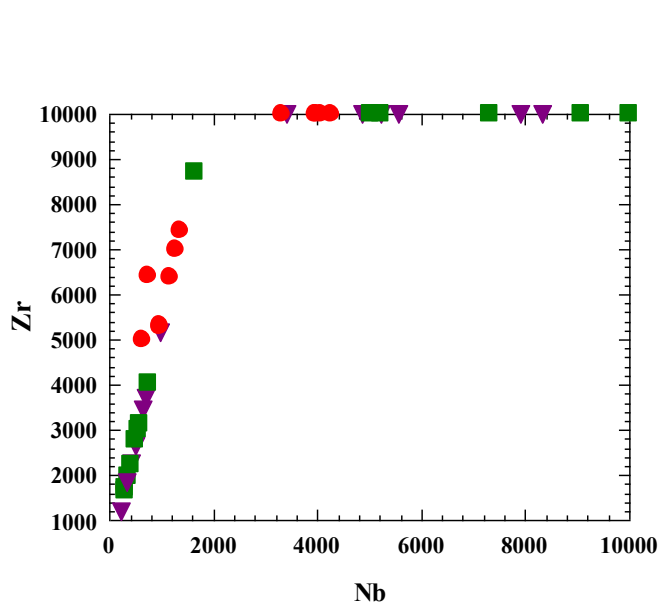

b)

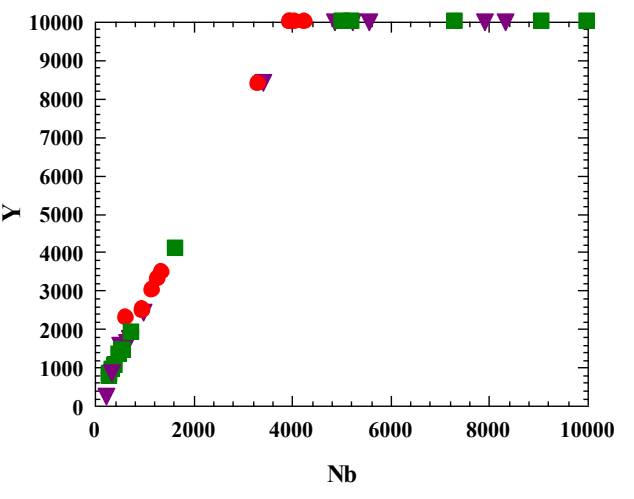

d)

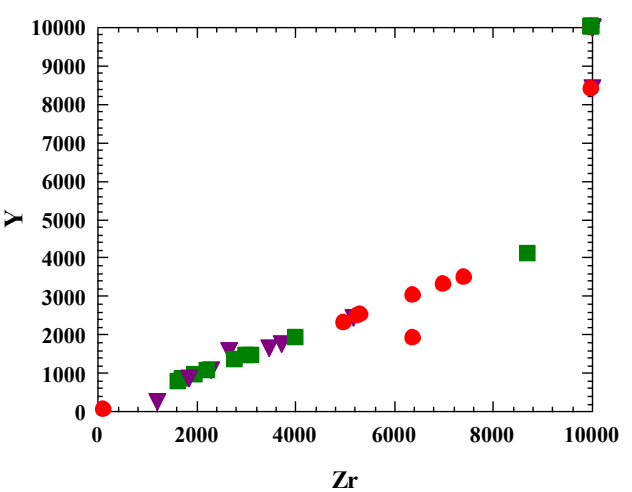

$-0.25$

$\nabla \quad-0.5-0.25$

$-1-0.5$

Fig. (8): Binary diagram shows: a)V \& Ga, b) Y \& Nb, c) Y \& V, d) Y \& Zr, e) Zr \& Nb. 
The results of chemical analysis for 17 samples representative the stream sediments in table (2) and relation between uranium and thorium are drawn with some trace elements Fig. (9). Uranium show strong (+ ve) relation with $\mathrm{Zr}, \mathrm{Nb}, \mathrm{Y}, \mathrm{Ga}$ and slightly (+ve) relation with $\mathrm{Pb}$, and irregular relation with
$\mathrm{Zn}$. While thorium show gently positive relation with $\mathrm{Zr}, \mathrm{Y}, \mathrm{Nb}, \mathrm{Pb}, \mathrm{Ga}$ and irregular relation with Zn. Uranium show relatively increase in $0.5 \mathrm{~m}$ and $1 \mathrm{~m}$ depth respectively while Th increase at $0.5 \mathrm{~m}, 1 \mathrm{~m}$ and $1.5 \mathrm{~m}$ with the position of sample.

Table (2) : Chemical concentration of uranium, thorium in ppm.

\begin{tabular}{|c|c|c|c|}
\hline Serial No. & Sample No. & U ppm & Th ppm \\
\hline 1 & $6-1$ & 300 & 268 \\
\hline 2 & $6-2$ & 240 & 225 \\
\hline 3 & $6-6$ & 200 & 350 \\
\hline 4 & - & - & - \\
\hline 5 & $6-8$ & 400 & 430 \\
\hline
\end{tabular}

\section{REEs distribution:}

The geochemistry of the rare earth elements (REEs) has been intensively studied in the past decades, and that the behavior of the REEs in most geological environments can be accounted for by differences in their ionic radii, (increasing contraction of the $5 \mathrm{~s}$ and $5 \mathrm{p}$ electron shell with increasing atomic mass) as well as variation in valence states $\left(\mathrm{Ce}^{+}\right.$or $\mathrm{Ce}^{4+}, \mathrm{Eu}^{2+}$ or $\left.\mathrm{Eu}^{4+}\right)$. Due to their large ionic radii and charge, the REEs as well as $\mathrm{U}$ and Th, behave incompatibly during magmatic process, The LREEs tend to be concentrated in highly fractionated basic rocks such as carbonatites (Forster, 2000).

The REEs in the studied area illustrate more than one depth, samples on the surface have +ve Eu anomaly Fig. (12a), while the middle samples on depth $(0.5 \mathrm{~m}, 1 \mathrm{~m})$ are similar to each other but differ from surface samples and chondrite Fig. 12(b, c), where they depleted in -ve Eu and Tm. The bottom depth, at $(1.5 \mathrm{~m})$ europium began to increase, also, Tm which may be an indication to increase in plagioclase Fig (12d). Whilst HREEs increase at (1m) depth where some minerals are concentrated (uranothorite, columbite), otherwise at depth $(0.5 \mathrm{~m})$
, (1.5m) HREEs are similar due to the increase in zircon, xenotime, garnet and thorite. (Ibrahim et al., 2007a) recorded the occurrence of REEs up to $(1.5 \%)$ in the studied lamprophyre dikes in Abu Rusheid. Microscopically lamprophyre dikes ( $\mathrm{L}_{1}$ and $\mathrm{L}_{2}$ ) are mainly composed of plagioclases, amphiboles, phlogopite, and relics of pyroxenes phenocrysts embedded in a fine-grained groundmass. Xenotime, fluorite, chlorite, and opaque are accessories. The feldspars and micas in both $\mathrm{L}_{1}$ and $\mathrm{L}_{2}$ lamprophyres are partially altered to clay minerals (chemical traps) while the oxidation of sulphide minerals left ocelli (physical traps), usually filled by calcite and U minerals (Ibrahim et al., 2015).

Since we find mainly the composition of the studied stream sediment samples table (3), similar petrographically to the altered lamprophyre dikes after (Ali, 2012; Ibrahim et al., 2015). In comparison with the previously mentioned, In addition the NNW-SSE lamprophyre dikes $\left(\mathrm{L}_{1}\right.$ and $\left.\mathrm{L}_{2}\right)$ are located in the core of the cataclastic rocks (Ibrahim, 2015). The cataclastic rocks (peralkalic granitic gneisses) are cross cut by NNW-SSE trending altered 

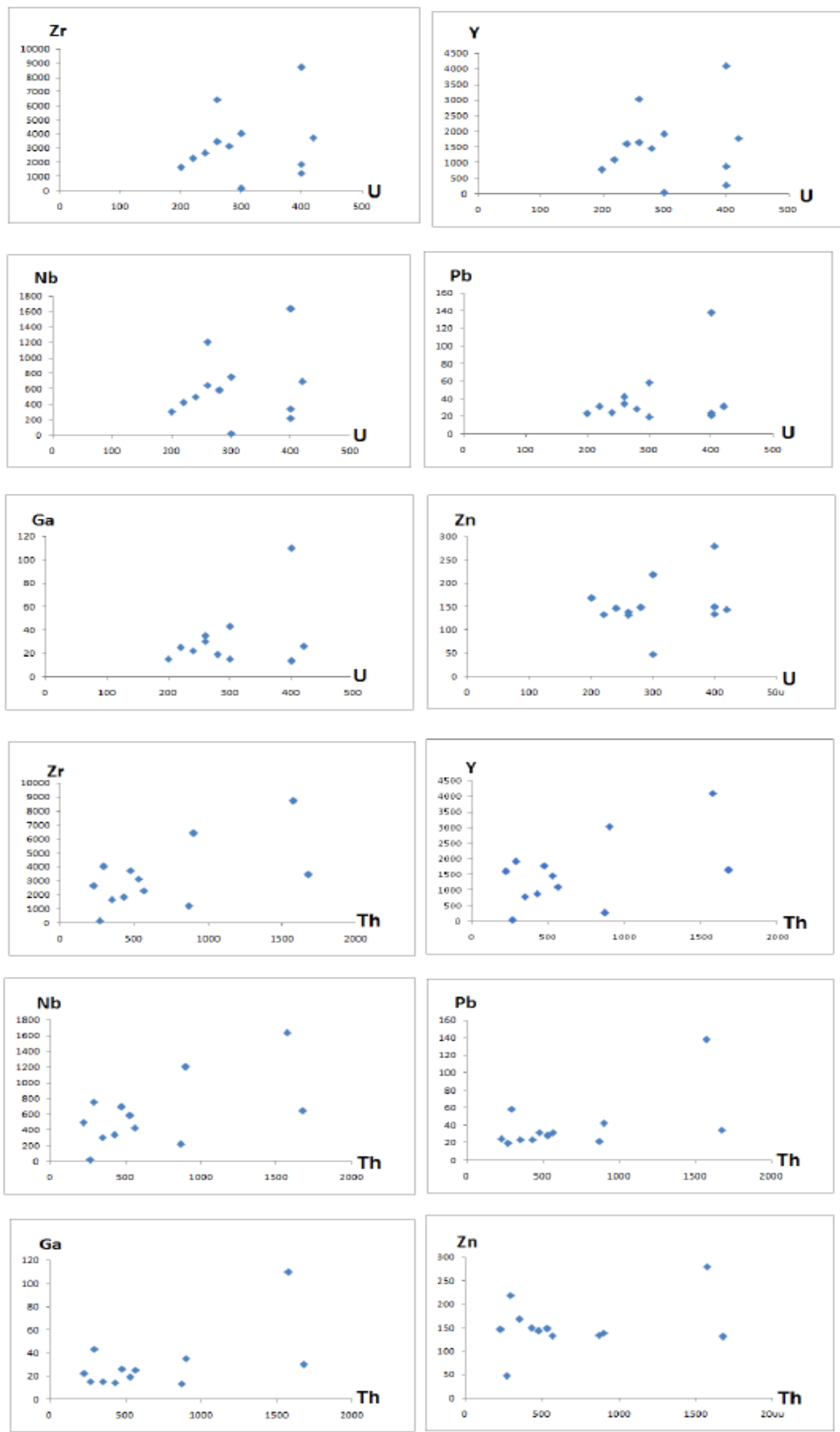

Fig. (9): The relation of U, Th with some trace elements. 


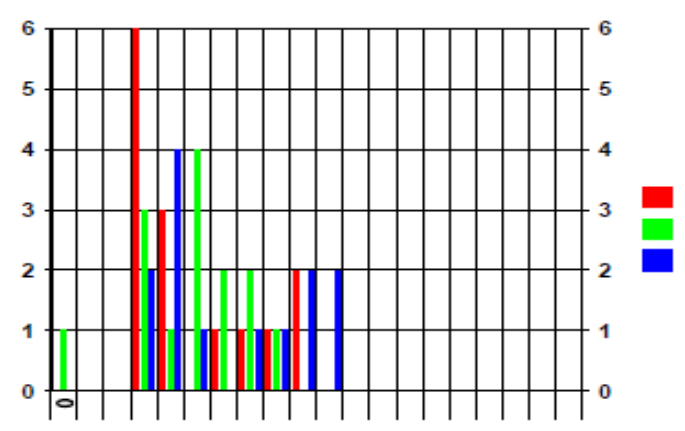

Histogram $\mathrm{Cr}$

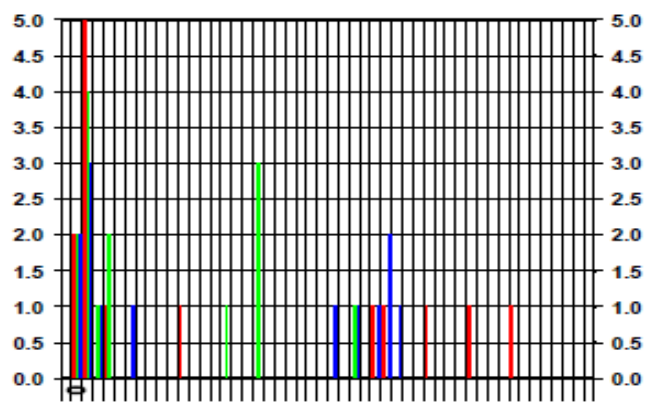

Histogram Ga

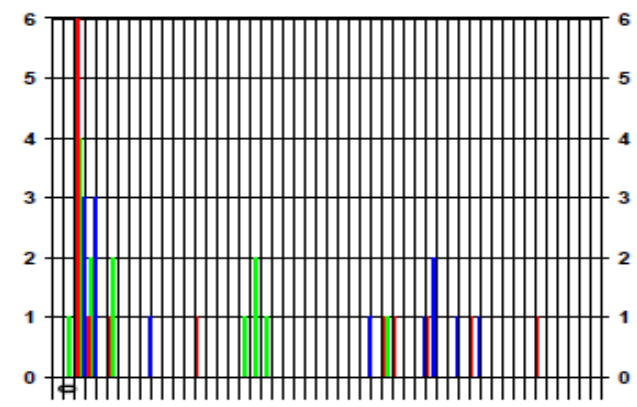

Histogram $\mathrm{Pb}$

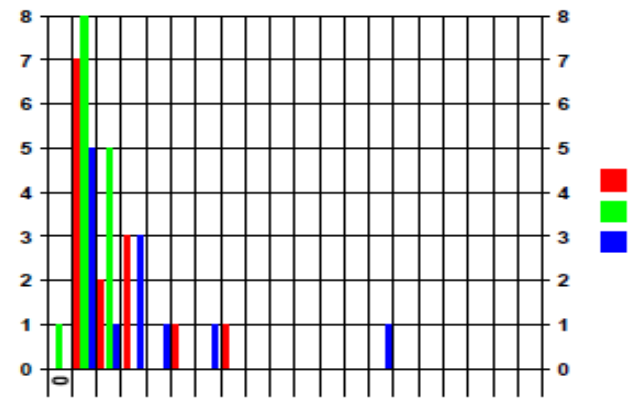

Histogram $\mathrm{Zn}$

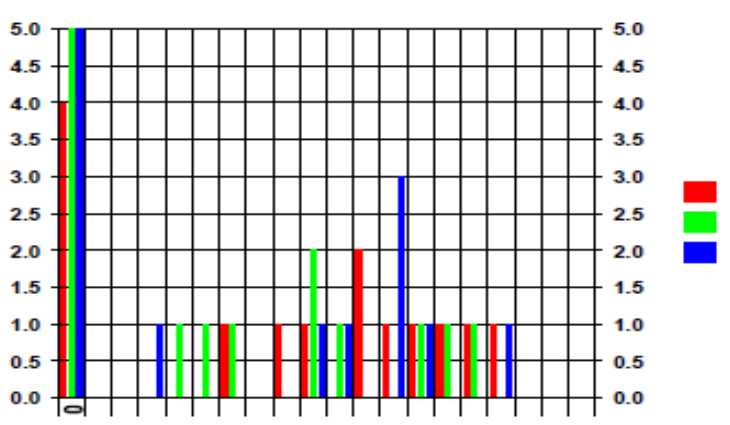

Histogram $\mathrm{Cu}$

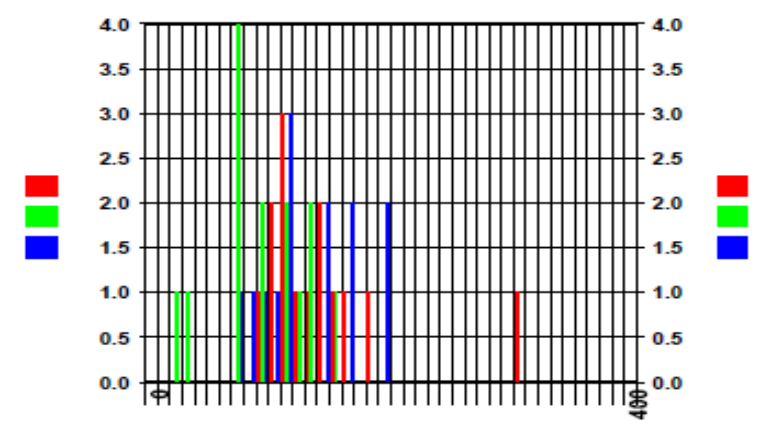

Histogram $\mathrm{Ni}$

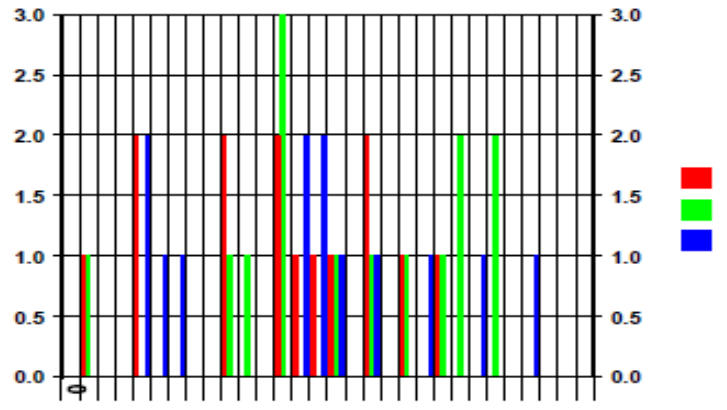

Histogram V

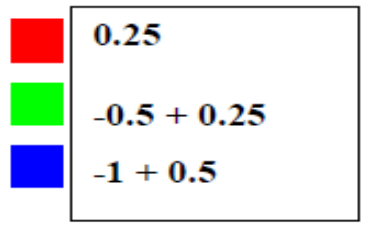

Fig. (10): Histogram show $\mathrm{Cr}, \mathrm{Cu}, \mathrm{Ga}, \mathrm{Ni}, \mathrm{Pb}, \mathrm{V}$ and $\mathrm{Zn}$ grain sizes. 

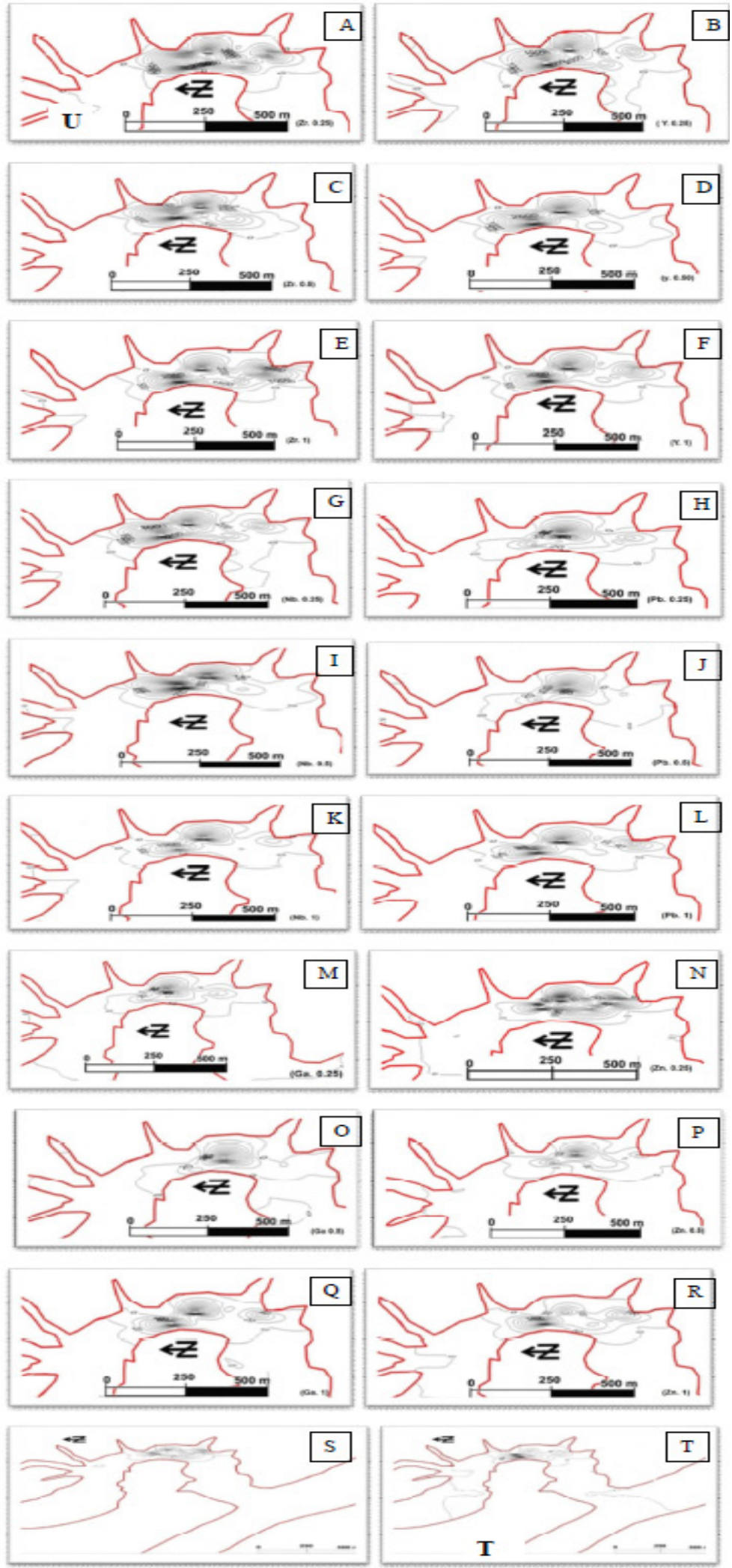

Fig. (11): Contour maps in grain sizes of $\mathrm{Zr}(\mathrm{A}, \mathrm{C}, \mathrm{E}), \mathrm{Y}(\mathrm{B}, \mathrm{D}, \mathrm{F}), \mathrm{Nb}(\mathrm{G}, \mathrm{I}, \mathrm{K}), \mathrm{Pb}(\mathrm{H}, \mathrm{J}, \mathrm{L}), \mathrm{Ga}(\mathrm{M}, \mathrm{O}, \mathrm{Q}), \mathrm{Zn}(\mathrm{N}, \mathrm{P}, \mathrm{R})$, $\mathrm{U}(\mathrm{S})$ and $\mathrm{Th}(\mathrm{T})$. 
and mineralized shear zone, the lamprophyre dikes were emplaced along shear zone filling in fracture planes (Ali, 2012). The author in the present study suggests that lamprophyre dike for example, $\left(\mathrm{L}_{1}\right.$ and
$\mathrm{L}_{2}$ ) with granitic gneisses shear zone is responsible for the increase of REEs percentage in the stream sediment study area.

Table (3) : Average of REEs on surface, at 0.5m, at $1 \mathrm{~m}$ and $1.5 \mathrm{~m}$ of stream sediment (in ppm) in Abu Rusheid.

\begin{tabular}{|c|c|c|c|c|c|}
\hline $\begin{array}{c}\text { Elements } \\
\mathrm{n}=3\end{array}$ & $\begin{array}{c}\text { Average on surface } \\
\mathrm{n}=3\end{array}$ & $\begin{array}{c}\text { at } 0.5 \mathrm{~m} \\
\mathrm{n}=3\end{array}$ & $\begin{array}{c}\text { At } 1 \mathrm{~m} \\
\mathrm{n}=3\end{array}$ & $\begin{array}{c}\text { At } 1.5 \mathrm{~m} \\
\mathrm{n}=3\end{array}$ & $\begin{array}{c}\text { Lamprophyres } \\
\mathrm{L}_{1}+\mathrm{L}_{2}\end{array}$ \\
\hline $\mathrm{La}$ & 145.05 & 146.4 & 150.13 & 13.03 & 199 \\
\hline $\mathrm{Ce}$ & 9.79 & 465.49 & 158.19 & 565.43 & 192 \\
\hline $\mathrm{Pr}$ & 13.2 & 62.32 & 30.46 & 64.52 & 110 \\
\hline $\mathrm{Nd}$ & $<0.01$ & 1081.5 & 2797.72 & 659.67 & 340 \\
\hline $\mathrm{Sm}$ & $<0.01$ & $<0.01$ & $<0.01$ & 3.61 & 141 \\
\hline $\mathrm{Eu}$ & 0.74 & $<0.01$ & $<0.01$ & 0.05 & 4 \\
\hline $\mathrm{Gd}$ & 32.59 & 45.81 & 64.32 & 60.07 & 167 \\
\hline $\mathrm{Tb}$ & $<0.01$ & $<0.01$ & $<0.01$ & $<0.01$ & 71 \\
\hline $\mathrm{Dy}$ & 14.36 & 89.18 & 114.12 & 92.09 & 689 \\
\hline $\mathrm{Ho}$ & 0.007 & $<0.01$ & $<0.01$ & $<0.01$ & 174 \\
\hline $\mathrm{Er}$ & 4.916 & 5213.44 & 10360.61 & 3171.95 & 843 \\
\hline $\mathrm{Tm}$ & 0.43 & $<0.01$ & $<0.01$ & 115.6 & 137 \\
\hline $\mathrm{Yb}$ & 4.07 & 189.77 & 272.9 & 185.82 & 1018 \\
\hline $\mathrm{Lu}$ & 0.99 & 34.99 & 51.08 & 33.98 & 151 \\
\hline$\Sigma \mathrm{LREEs} / \Sigma \mathrm{HREEs}$ & 2.8 & 0.32 & 0.29 & 0.36 & 0.14 \\
\hline
\end{tabular}

N number of samples, <0.01 under detection limits - Lamprophyres comparison after (Ibrahim et al., 2015).

\section{Controlling factors of the REEs distribution:}

In surficial environments, although, it is believed that REEs show low mobility and are resistant to fractionation during weathering processes.

First factor, weathering of minerals parent rocks causes mobilization of elements and fractionation of LREEs and HREEs of Ce and / or Eu (Maclean $\boldsymbol{e t}$ al., 1997; Hill et al., 2000 and Patino et al., 2003).

Second factor; $\mathrm{PH}$ is the dominant parameter controlling REEs mobility, under acidic conditions REEs are easily removed from weathering products, absorbed on all types of minerals and amorphous surface coating during koalinization and lateritization, fixed by major scavengers under neutral to alkaline conditions (Nesbitt, 1979 and Fleet, 1984).

(i) The chondrite normalized REEs patterns of all samples, it is reported that $\mathrm{Ce}$ is usually retained in the upper parts of the weathering profiles due to the oxidation of Ce (III) to Ce (IV), (Nyakariu et al., 
2001 and Compton et al., 2003). We notice slight negative $\mathrm{Ce}$ anomalies and higher in other light elements REEs content. Otherwise, some samples contrastingly, where the REEs pattern has positive $\mathrm{Ce}$ anomalies. This may be explained by combined effect of selective remobilization of Ce (IV) could have been initiated during cycles of the stream sediments where chemically reworked.

At the surface and $(0.5 \mathrm{~m}$ and $1 \mathrm{~m})$ depth, the negative correlation of $\mathrm{Ce}$ could be the result of the two stages, the first stage, Ce might have been positively correlated with $\mathrm{Fe}$ scavenging of REE by Fe oxyhydroxides is a wide spread phenomenon (Bau et al., 1996; De Carlo et al., 1998; Bau 1999 \& Ohta and Kawabe, 2001).

Second stage, mainly $\mathrm{Ce}$ was mobilized at $\mathrm{PH}$ above 8 , complexes of $\mathrm{Ce}$ (IV) are most stable in acidic environment besides free REE ions (Janssen and Verweij, 2003; Roy and SmyKatz Kloss, 2007 \& Steinmann and stille, 2006). Whereas less stable REE (III) complexes are adsorbed by scavengers such as Al-Mg hydro silicates and Ti oxides, In the top layer (surface) this explains the + ve anomalie in Gd, Dy and Er. In addition to high partition coeffi-
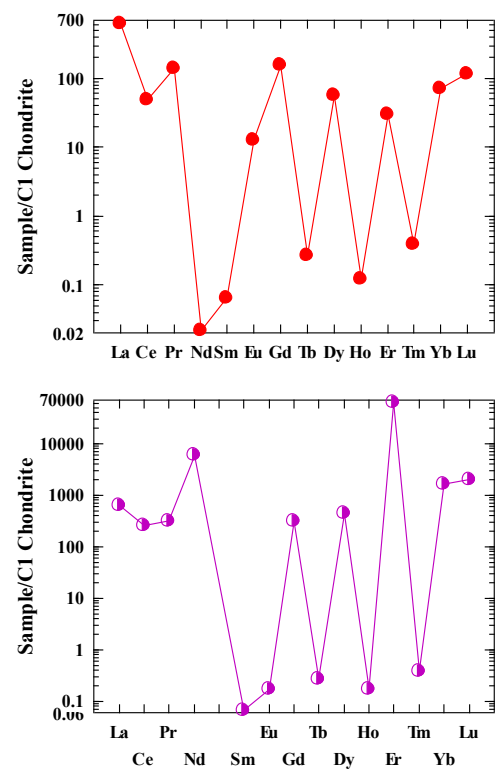

cient between Gd, Dy and Er in hornblende (10, 13, 12), respectively (Watson and Harrison, 1983). Fig. (12) Ce (IV) complexation have transported to deeper zones where it is adsorbed or precipitated, nearly at $1.5 \mathrm{~m}$ depth.

(ii) Enrichment in the middle REEs relative to the light and heavy are REE is chiefly controlled by hornblende. The REEs are compatible in hornblende in felsic and intermediate liquids and the highest partition coefficients are between Dy and Er. Such large partition coefficients mean that even a moderate amount of hornblende, according to (Rollinson, 1993).

(iii) Eu anomalies, samples in the Fig. $12(\mathrm{~b}, \mathrm{c})$ show negative $\mathrm{Eu}$ anomaly that may be inherited from the felsic precursor rocks a consequence of preferential leaching of $\mathrm{Eu}$ associated with the breakdown of feldspar (plagioclase) in direction of upstream sediment, suggesting that plagioclase free sediments are downstream in the studied area (Taylor and Mclennan 1988; White et al., 2001 and Villaseca et al., 2003), samples on depth suggests the same source of formation. These relationships are explicable when assuming deposition of stream sediment of Abu Ruheid, (Ozturk et al., 2002).
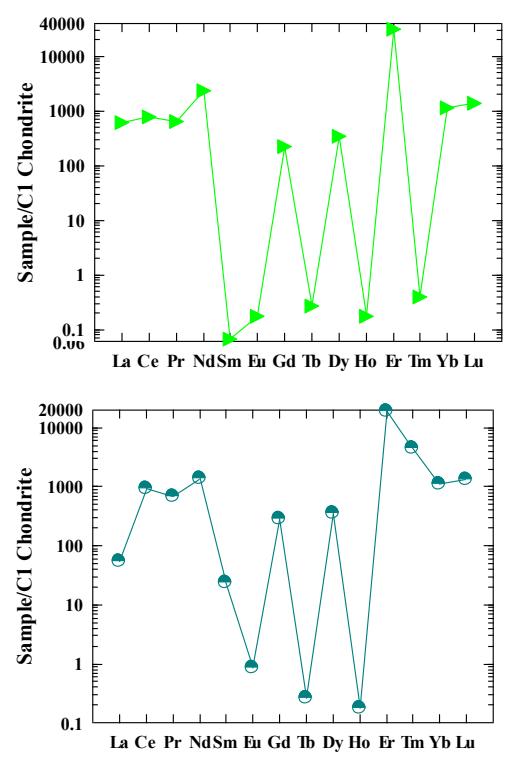

Fig. (12): Chondrite-normalized REEs patterns for the stream sediments, (a) average samples on surface, (b) samples at $0.5 \mathrm{~m}$ depth, (c) samples at $1 \mathrm{~m}$ depth, (d) samples at 1.5m depth, Abu Rusheid area, South Eastern Desert, Egypt. Normalizing chondritic values after (Sun, 1980). 


\section{CONCLUSION}

(i) The data obtained in this study proved that controlling factors of distribution of rare earth elements and mobility of $U$, valuable radioelements come from leaching of more labil REEs bearing minerals from granitic gneisses rocks cut by mineralized shear zone and green silicates mainly amphiboles (hornblende). Part of the studied stream sediments samples composition is petrographically similar to the altered lamprophyre dike which is mainly composed of plagioclase, amphibole (H.b), relics pyroxenes, muscovite and chlorite, in addition; the cataclastic rocks (peralkalic granitic gneisses) are cross cut by NNW-SSE trending altered and mineralized shear zone (Ali, 2012). From the comparison of the REEs in the studied stream sediments resembles those of the studied lamprophyre dikes $\left(\mathrm{L}_{1}\right.$ and $\mathrm{L}_{2}$ ) Ibrahim et al., (2015), since we find the majority of minerals in the surface samples of stream sediments for example, amphibole (hornblende), allanite, geothite, few pyroxene, few garnet. Under surficial weathering (epigene), the breakdown of allanite give monazite, clay minerals, cerianite and geothite where $\mathrm{Ce}$ and $\mathrm{Nd}$ rich allanite indicate concentrated LREEs during a late hydrothermal alteration, while recorded geothite on surface represents the secondary phase and is considered as the main criteria for chemical weathering.

So, under acidic condition REEs are easily removed from weathering product, adsorbed on all types of minerals and amorphous surface coating during kaolinization and lateritization fixed by major scavengers under neutral to alkaline condition.

(ii) Geochemical study of drawing binary relations of $\mathrm{U}, \mathrm{Th}$ and some trace elements clarified that uranium increase with $\mathrm{Zr}, \mathrm{Nb}, \mathrm{Y}, \mathrm{Zn}$, and slightly increase with $\mathrm{Ga}$ and $\mathrm{Pb}$. While thorium show accumulation at the beginning with $\mathrm{Zr}, \mathrm{Y}, \mathrm{Nb}$, $\mathrm{Ga}$ then show dispersed relation with $\mathrm{Pb}, \mathrm{Zn}$. (iii) In addition, histograms show that $\mathrm{Ga}, \mathrm{Zn}$ and $\mathrm{Pb}$ are rich in grain size $0.25 \mathrm{~mm}$ and $-0.5+$ 0.25 while other elements $(\mathrm{Cr}, \mathrm{Ni}, \mathrm{Cu}$, and $\mathrm{V})$ are moderately rich in all size.

(iv) On the basis of the trace elements content we drawn the geochemical contour maps to explore the mineralization extension in deep levels from surface $(0.5 \mathrm{~m}, 1 \mathrm{~m}, 1.5 \mathrm{~m})$ of stream sediments according to distribution in Wadi Abu Rusheid. We notice that valuable trace elements take the same direction of peralkalic granitic gneisses and lamprophyre dikes where $\mathrm{Zr}, \mathrm{Y}, \mathrm{Pb}$ and $\mathrm{Ga}$ in size $(-1+0.5)$ show the highest concentration in NNW-SSE direction and $\mathrm{Nb}$ in size $(-0.5+0.25)$ take the same direction, while higher concentration of $\mathrm{Zn}$ in size (-0.25) take NENW, otherwise U take NW-SE and Th take NW to NS direction.

(v) Finally, by drawing chondrite-normalized patterns, The REEs in the studied area illustrate more than one depth, samples on the surface have +ve Eu anomaly, while the middle samples on depth $(0.5 \mathrm{~m}, 1 \mathrm{~m})$ are similar to each other but differ from surface samples and chondrite, where they depleted in -ve Eu and Tm. The bottom depth at $(1.5 \mathrm{~m})$ europium began to increase, also, Tm which may be an indication to increase in plagioclase. Whilst HREEs increase at $(1 \mathrm{~m})$ depth where some minerals are concentrated (uranothorite, columbite), otherwise at $(0.5 \mathrm{~m})$ and $(1.5 \mathrm{~m})$ depth HREEs are similar due to the increase in zircon, xenotime, garnet and thorite.

\section{ACKNOWLEDGMENT}

The author: Thanks to Prof. Dr/ Hamdy Abduallah, Dr/ Anton, Especially grateful for Prof. Dr/ Josef. And Dr/ Ehab Korany.

\section{REFERENCES}

- Abd El-Monem, A.A. and Hurley, P.M. (1979): $\mathrm{U}-\mathrm{Pb}$ dating of zircon from psammitic gneisses, wadi Abu Rusheid-wadi Sikait area, Egypt. In Evolution and Mineralization of the Arabian-Nubian Shield 
(Vol. 2), pp. 70

- Abdalla, H.M.; Ishihara, S.; Matsueda, H. and Monem, A.A.A. (1996): On the albite-enriched granitoids at Um Ara area, Southeastern Desert, Egypt. 1. Geochemical, ore potentiality and fluid inclusion studies. J. Geoch. Exp., 57(1): 127.

- Ali, M.A. (2012): Mineral chemistry of monazite(Nd), xenotime-(Y), apatite, fluorite and zircon hosting in lamprophyre dyke in Abu Rusheid area, South Eastern Desert, Egypt. Geologija, 55(1): 93.

- Ali, M.A.; Lentz, D.R. and Hall, D.C. (2011): Mineralogy and geochemistry of Nb-, Ta-, Sn-, U-, Th-, and Zr-bearing granitic rocks from Abu Rusheid shear zones, South Eastern Desert, Egypt. Chinese J. Geochem., 30(2): 226.

- Andrehs, G. and Heinrich, W. (1998): Experimental determination of REE distributions between monazite and xenotime: potential for temperature-calibrated geochronology. Chem. Geol., 149(1): 83.

- Bau, M. (1999): Scavenging of dissolved yttrium and rare earths by precipitating iron oxyhydroxide: experimental evidence for Ce oxidation, Y-Ho fractionation, and lanthanide tetrad effect. Geochim. Cosmochim. Acta, 63(1): 67.

- Bau, M.; Koschinsky, A.; Dulski, P. and Hein, J.R. (1996): Comparison of the partitioning behaviours of yttrium, rare earth elements, and titanium between hydrogenetic marine ferromanganese crusts and seawater. Geochim. Cosmochim. Acta, 60(10): 1709.

- Beus, A.A. (1962): Albitized and Greisenized Granites (Apogranites). The USSR Academy of Science, 196 P., Moscow, Russia.

- Bugrov, V.A.; El-Gadael, A.A., and Soliman, M.M. (1973): Rare metallic albetites as a new type of mineralization in egypt. Annals Geol. Surv. Egypt, 111: 185.

- Calagari, A.A., and Abedini, A. (2007): Geochemical investigations on Permo-Triassic bauxite horizon at Kanisheeteh, east of Bukan, West-Azarbaidjan, Iran J. Geoch. Exp., 94(1): 1.
- Carlo, E.H.D.; Wen, X.Y., and Irving, M. (1997): The Influence of Redox Reactions on the Uptake of Dissolved Ce by Suspended Fe and Mn Oxide Particles. Aquatic Geochem., 3(4): 357.

- Compton, J.S.; White, R.A. and Smith, M. (2003): Rare earth element behavior in soils and salt pan sediments of a semi-arid granitic terrain in the Western Cape, South Africa. Chem. Geol., 3-4(201): 239.

- El-Afandy, A. H.; Abdalla, H. M.; Assran, H.M.; Abou El Fetouh, A.A. and Moghazi, N.M. (2003): Evaluation of Placer Deposits of Radioactive and Nuclear Elements at Wadi Abu Rusheid Area, Southern Eastern Desert, Egypt. Internal Report of Nuclear Material Authority, $69 \mathrm{p}$.

- El-Afandy, A.H.; Abdalla, H.M.; Aly, M.M., and Ammar, F. (2000): Geochemistry and Radioactive Potentiality of Um Naggat Apogranite, Central Eastern Desert, Egypt. Resource Geol., 50(1): 39.

- Fleet, A.J. (1984): Aqueous and sedimentary geochemistry of the rare earth elements. In: Henderson, P. (Ed.), Developments in Geochemistry (Vol. 2), Elsevier, pp. 343.

- Fletcher, W.K.; Church, M. and Wolcott, J. (1992): Fluvial-transport equivalence of heavy minerals in the sand size range. Can. J. Earth Sci., 29(9): 2017.

- Forster, H.J. (2000): Cerite-(Ce) and thorian synchysite-(Ce) from Niederbobritzsch (Erzgebirge, Germany): implications for the differential mobility of Th and the LREE during granite alteration. Can. Mineral., 38: p. 67.

- Fritz, H.; Dallmeyer, D.R.; Wallbrecher, E.; Loizenbauer, J.; Hoinkes, G.; Neumayr, P. and Khudeir, A.A. (2002): Neoproterozoic tectonothermal evolution of the Central Eastern Desert, Egypt: a slow velocity tectonic process of core complex exhumation. J. Afri. Earth. Sci., 34(3): 137.

- Greiling, R.O.; Ramly, M.E.E.; Rashwan, A.A. and Kamal EI Din, G.M. (1993): Towards a comprehensive structural synthesis of the (Proterozoic) Arabian-Nubian Shield in E.Egypt. In Geoscientific Research in Northeast Africa (Heinz Schandelmeier, 
Ulf Thorweihe, pp. 15). Balkema, Rotterdam.

- Heinrich G.W. (1958): Mineralogy of radiactive raw materials. McGraw Hill Book Co., New York, 654p.

- Hill, I. G.; Worden, R. H. and Meighan, I.G. (2000): Geochemical evolution of a palaeolaterite: the Interbasaltic Formation, Northern Ireland. Chem. Geol., 166(1): 65.

- Hilmy, M.E.; Bayoumi, R.M. and Eid, A.S. (1990): Geochemistry and mineralization of the psammitic gneiss of the Wadi Abu Rushied, Eastern Desert, Egypt. J. Afri. Earth Sci., 11, 197.

- $\quad$ Ibrahim, I.; Saleh, G.M.; Amer, T.; Mahmoud, F.; Abu El Hassan, A.; Ali, M.A.; Azab, M.S.; Rashed, M.; Khaleal, F. and Mahmoud, M. (2004): Uranium and Associated Rare Metals Potentialities of Abu Rusheid Brecciated Shear Zone II, South Eastern Desert, Egypt [M]. Nuclear Materials Authority, Internal Report, Cairo: 182 p.

- Ibrahim, M.E.; Saleh, G.M.; El-Tokhi, M.M. and Rashed. M. (2007a): A Lamprophyre bearing-REEs in Abu Rusheid area, Southeastern Desert, Egypt. The $7^{\text {th }}$ Inter. Confer. Geo., Alex. Uni., pp.30.

- Ibrahim, M.E.; Watanabe, K.; Saleh, G.M. and Ibrahim, W.S. (2015): Abu Rusheid lampro-phyre dikes, South Eastern Desert, Egypt: as physicalchemichal traps for REEs, Zn, Y, U, Cu, W and Ag. Arab J. Geosci., 8(11): 9261.

- Janssen, R.P.T., and Verweij, W. (2003): Geochemistry of some rare earth elements in groundwater, Vierlingsbeek, The Netherlands. Water Res., 37(6): 1320 .

- Liaghat, S.; Hosseini, M. and Zarasvandi, A. (2003): Determination of the origin and mass change geochemistry during bauxitization process at the Hangam deposit, SW Iran. Geochem. J., 37(5): 627.

- MacLean, W. H. and Kranidiotis, P. (1987): Immobile elements as monitors of mass transfer in hydrothermal alteration; Phelps Dodge massive sulfide deposit, Matagami, Quebec. Econ. Geol., 82(4): 951.

- MacLean, W.H., Bonavia, F. F. and Sanna, G.
(1997): Argillite debris converted to bauxite during karst weathering: evidence from immobile element geochemistry at the Olmedo Deposit, Sardinia. Miner. Depos., 32(6): 607.

- Mathew, K.J.; Bürger, S.; Ogt, S.V.; Mason, P.M.E.M. and Narayanan, U. I. (2009): Uranium assay determination using Davies and Gray titration proceedings of The Eighth International Conference on Methods and Applications of Radioanalytical Chemistry (Marc Viii) Kailua-Kona, Hawaii, 5.

- Meintzer, R.E. and Mitchell, R.S. (1988): The epigene alteration of allanite. Can. Mineral., 26: 945.

- Merczenko, Z. (1986): Separation and Spectrophotometric Determination of Elements." Harwood, New York, 708 p.

- Moghazi, A.M.; Hassanen, M.A.; Mohamed, F.H. and Ali, S. (2004): Late Neoproterozoic strongly peraluminous leucogranites, South Eastern Desert, Egypt - petrogenesis and geodynamic significance. Miner. Petrol., 81(1-2): 19.

- Nesbitt, H.W. (1979): Mobility and fractionation of rare earth elements during weathering of a granodiorite. Nature, 279(5710): 206.

- Nyakairu, G.W.A. and Koeberl, C. (2001): Mineralogical and chemical composition and distribution of rare earth elements in clay-rich sediments from central Uganda. Geochem. J., 35(1): 13.

- Ohta, A. and Kawabe, I. (2001): REE (III) adsorption onto $\mathrm{Mn}$ dioxide $(\delta-\mathrm{MnO} 2)$ and $\mathrm{Fe}$ oxyhydroxide: Ce (III) oxidation by $\delta-\mathrm{MnO} 2$. Geochim. Cosmochim. Acta, 65(5): 695.

- Öztürk, H.; Hein, J.R. and Hanilci, N. (2002): Genesis of the Doğankuzu and Mortaş Bauxite Deposits, Taurides, Turkey: Separation of Al, Fe, and Mn and Implications for Passive Margin Metallogeny. Econ. Geol., 97(5):1063.

- Patino, L.C.; Velbel, M.A.; Price, J.R., and Wade, J.A. (2003): Trace element mobility during spheroidal weathering of basalts and andesites in Hawaii and Guatemala. Chem. Geol., 202(3): 343. 
- Price, J.R.; Velbel, M.A. and Patino, L.C. (2005): Allanite and epidote weathering at the Coweeta Hydrologic Laboratory, western North Carolina, U.S.A. Am. Mineral., 90: 101.

- Pupin, J.P.; Bonin, B.; Tessier, M. and Turco, G. (1978): Role de l'eau sur les caracteres morphologiques et la cristallisation du zircon dans les granitoides. Bull. Soc. Géol. Fr., S7-XX(5): 721.

- Rollinson, H.R. (1993): Using geochemical data: evolution, presentation, interpretation. John Wiley and Sons, New York.

- Roy, P.D. and Smykatz-Kloss, W. (2007): REE geochemistry of the recent playa sediments from the Thar Desert, India: An implication to playa sediment provenance. Chem. Erde-Geochem., 67(1): 55.

- Rubey, W.W. (1933): The size distribution of heavy minerals within a water-laid sandstone. J. Sediment. Res., 3(1): 3 .

- Speer, J.A. (1982a): Zircon. In: Reviews in Mineralogy (vol. 5: $2^{\text {nd }}$ edition) Orthosilictes, Ribbe, P.H. (ed.), pp. 67.

- Speer, J.A. (1982b): The actinides orthosilicates. In: Reviews in Mineralogy (vol. 5: $2^{\text {nd }}$ edition) Orthosilictes, Ribbe, P.H. (ed.), pp. 113.

- Spurgin, S.; Selbekk, R. and Lundmark, M. (2009): Mineralogy and geological setting of allanite (Ce)- pegmatites in western Hurrungane, Jotun Nappe Complex, Norway: an EMP and ID-TIMS study. Norw. J. Geol., 89: 341.

- Steinmann, M. and Stille, P. (2006): Rare earth element transport and fractionation in small streams of a mixed basaltic-granitic catchment basin (Massif Central, France). J. Geoch. Exp., 88(1): 336.

- Sun, S.S. (1982): Chemical composition and origin of the Earth's primitive mantle, Geochim. Cosmochim. Acta, 46: 179.
- Taylor, G. and Eggleton, R.A. (2001): Regolith Geology and Geomorphology: John Wiley \& Sons, Ltd., New York, 375 p.

- Taylor, S.R. and McLennan, S.M. (1988): The significance of the rare earths in geochemistry and cosmochemistry. In: Handbook on the Physics and Chemistry of Rare Earths, (Vol. 11) Karl, A.; Gschneidner, Jr. and L. Eyring (eds.), Elsevier, pp. 485.

- Vavra, G. (1990): On the kinematics of zircon growth and its petrogenetic significance: a cathodoluminescence study. Contrib. Mineral Petrol., 106(1): 90.

- Villaseca, C.; Martín Romera, C.; De la Rosa, J. and Barbero, L. (2003): Residence and redistribution of REE, Y, Zr, Th and U during granulite-facies metamorphism: behaviour of accessory and major phases in peraluminous granulites of central Spain. Chem. Geol., 200(3-4): 293.

- Watson, E.B. and Harrison, T.M. (1983): Zircon saturation revisited: temperature and composition effects in a variety of crustal magma types. Earth Planet Sci. Lett., 64: 295.

- White, A. F.; Bullen, T.D.; Schulz, M.S.; Blum, A.E.; Huntington, T.G. and Peters, N.E. (2001): Differential rates of feldspar weathering in granitic regoliths. Geochim. Cosmochim. Acta, 65(6): 847.

- Wood, S.A. and Ricketts, A. (2000): Allanite-(Ce) from the Eocene Casto Granite, Idaho: Response to hydrothermal alteration. Can. Mineral., 38: 81.

- Yuanming, P. and Michael, E. F. (1991): Anadian allanite-(La) and anadian allanite-(Ce) from the Hemlo Gold Deposit, Onatrio. Can. Mineral., 55(381): 497. 